Discussion Papers
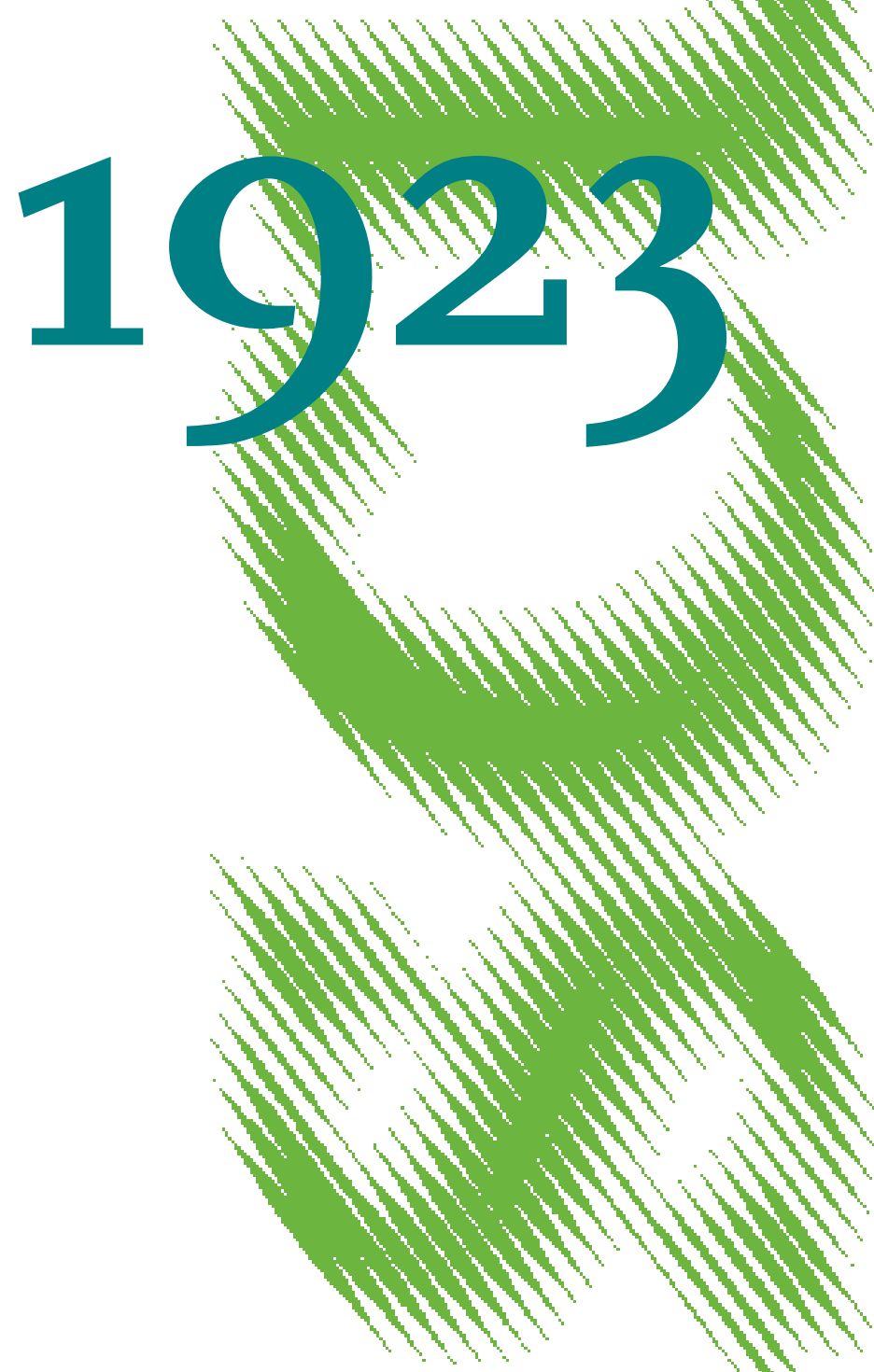

EU Sustainable Finance Taxonomy

- What Is Its Role on the Road towards Climate Neutrality? 
Opinions expressed in this paper are those of the author(s) and do not necessarily reflect views of the institute.

IMPRESSUM

(C) DIW Berlin, 2020

DIW Berlin

German Institute for Economic Research

Mohrenstr. 58

10117 Berlin

Tel. +49 (30) $89789-0$

Fax +49 (30) $89789-200$

http://www.diw.de

ISSN electronic edition 1619-4535

Papers can be downloaded free of charge from the DIW Berlin website:

http://www.diw.de/discussionpapers

Discussion Papers of DIW Berlin are indexed in RePEc and SSRN:

http://ideas.repec.org/s/diw/diwwpp.html

http://www.ssrn.com/link/DIW-Berlin-German-Inst-Econ-Res.html 


\title{
EU Sustainable Finance Taxonomy - what is its role on the road towards climate neutrality?
}

\author{
Franziska Schütze*, Jan Stede*
}

The EU Taxonomy is the first standardised and comprehensive classification system for sustainable economic activities. It covers activities responsible for up to 80 percent of EU greenhouse gas emissions and may play an important role in channelling investments into low-carbon technologies by helping investors to make informed decisions. However, especially in transition sectors much depends on the stringency of the technical performance thresholds that the Taxonomy applies to economic activities that are not yet "green". This paper shows that for several sectors, the thresholds are not yet on track to support the transition towards climate neutrality. To this end, we analyse a large-scale public consultation with detailed responses to the specific thresholds from a variety of stakeholders. Two distinct use cases of the Taxonomy complicate the use of a single threshold for emission-intensive sectors: For new investments, criteria need to be stricter than for current activities of companies. We also argue that for the sectors not covered by the Taxonomy, there is a need to differentiate between low-emissions activities and high-emission activities that are incompatible with a low-carbon future.

Keywords: EU Taxonomy; sustainable finance; classification system; green investments JEL codes: G00, G14, G18, Q01, Q54, Q56

\footnotetext{
* German Institute for Economic Research (DIW Berlin), Mohrenstr. 58, 10117 Berlin, Germany. E-mails: fschuetze@diw.de (F. Schütze), jstede@diw.de (J. Stede).
} 


\section{Background and introduction}

The past years have shown an increase in volume of sustainable investment funds and sustainability indices (FNG, 2020). Additionally, public actors are setting climate targets and governments are issuing green sovereign bonds. This has led to a multitude of classification systems for sustainability, resulting in a lack of transparency and comparability. The EU Taxonomy for sustainable activities is the first comprehensive science-based classification system designed to help understand whether an economic activity is sustainable. It provides a common definition for around 80 sustainable activities by setting performance thresholds (or technical screening criteria) for these activities (see annex). One goal is to make Taxonomy-related disclosure mandatory for large companies in the European Union. Ultimately, this is expected to help channel investments into low-carbon technologies, supporting the EU's transition towards climate neutrality by 2050 (IRENA, 2017; European Commission, 2018a, 2020a; McCollum et al., 2018; Sweatman and Hessenius, 2020). Moreover, the Taxonomy can act as an international benchmark for other jurisdictions developing their own taxonomies.

The Taxonomy is the basis for several related initiatives under the Commission's action plan on sustainable finance (European Commission, 2018b). A multitude of stakeholders will be affected directly or indirectly by the EU Taxonomy (TEG, 2020a). First, large companies reporting under the non-financial reporting Directive (NFRD) will need to disclose the share of their Taxonomy-aligned activities by 2022. Second, financial market participants offering sustainable financial products need to start disclosing their Taxonomy-aligned activities or investments for different market segments) by December 2021. The Taxonomy may therefore be used as a common definition for green financial products via the EU Ecolabel (Hessenius et al., 2020), as well as the EU green bond standard.

The Taxonomy provides non-financial information and can therefore ne expected to reduce information asymmetry (Dhaliwal et al., 2012; Cho et al., 2013). It may also create incentives for more investments into sustainable activities: So far, carbon emissions are commonly disclosed due to voluntary initiatives in some countries and regulatory standards in other countries (Hahn et al., 2015). Downar et al (2019) present evidence that mandatory carbon disclosure had a positive effect on the carbon performance of companies in the UK. A similar effect could result from the increased transparency the Taxonomy provides. Moreover, companies with a higher share of Taxonomyaligned activities may benefit from lower costs of capital (Kapraun and Scheins, 2019; Zerbib, 2019).

The Taxonomy may also be used as a support device for public investments into green technologies. EU institutions or national bodies, for example, may use the Taxonomy as a screening tool for public investments or subsidy programmes. As an example, the German development bank KfW has launched its loan programme Klimaschutzoffensive für den Mittelstand in March 2020, where investments in line with the EU Taxonomy benefit from a "climate grant" of up to six percent. Furthermore, the European Investment Bank has recently pledged to increase the climate share in its financing activities to $50 \%$ by 2025 , thereby using the EU Taxonomy as a main reference point (EIB, 2020).

The currently proposed Taxonomy, developed by a technical expert group (TEG) and put into law by EU delegated acts, focuses on activities that contribute to climate change mitigation and 
adaptation (European Commission, 2020b; TEG, 2020b). ${ }^{1}$ In order to be included in the Taxonomy, economic activities need to "substantially contribute" to climate change mitigation or adaptation, without doing significant harm to people ("minimum social safeguards") and other environmental objectives ("do no significant harm" criteria). The activities covered by the Taxonomy are typically characterised by high direct $\mathrm{CO}_{2}$ emissions (scope 1 emissions) and thus a large potential for climate change mitigation. Economic activities that are incompatible with net-zero emissions and where technological alternatives exist (e.g. the burning of fossil fuels for the generation of electricity), are not included in the taxonomy.

In this paper, we scrutinise the EU Taxonomy and its role on the pathway towards a net-zero economy. We differentiate between two types of applications (or use cases) of the Taxonomy: On the one hand, the Taxonomy may be used to evaluate the climate performance of a specific investment (such as a new manufacturing plant). On the other hand, the Taxonomy may be used to evaluate a company or a portfolio of assets, for example when providing a loan or equity to a company. The screening criteria need to be evaluated in light of these two distinct applications.

First, we describe the economic activities covered by the Taxonomy, and identify gaps of emissionsintensive sectors that are currently not covered by the Taxonomy. Second, we analyse whether the screening criteria proposed by the Taxonomy are compatible with a pathway towards climate neutrality in a next step. For this purpose, we classify economic activities into three types, namely activities that are eligible without a threshold ("green" or "enabling"), activities that have a threshold with a pathway towards climate neutrality, and activities with a threshold but without a pathway towards climate neutrality. Our assessment is based on an in-depth quantitative and qualitative evaluation of the official public consultation on the interim report of the EU Taxonomy (TEG, 2019), as well as a broader literature review. Finally, we discuss options to complement the Taxonomy, in case the use of technical thresholds alone does not incentivise investments into technologies compatible with climate neutrality.

The paper is structured as follows. Section 2 describes the data and methodology. Section 3 discusses two distinct use cases for the Taxonomy, as well as its sectoral coverage. Section 4 introduces a classification system for economic activities based on the Taxonomy and discusses performance thresholds for a selection of sectors. Sector 5 discusses the results and concludes.

\section{Data and methodology}

Our analysis builds on an extensive evaluation of the official EU consultation on the TEG interim report released in June $2019 .^{2}$ In this consultation, stakeholders were asked to comment in detail on each of the activities listed in the Taxonomy. A total of 642 stakeholders took part in the consultation,

\footnotetext{
1 The EU's Taxonomy Regulation (2020/852) was adopted in June 2020. Based on the TEG's report, draft delegated acts were published by the Commission in November 2020. By the end of 2021, screening criteria for four other environmental objectives, "protection of marine and water resources", "transition to a circular economy", "pollution prevention and control", and "protection and restoration of biodiversity and ecosystems", will be developed.

${ }^{2}$ For most activities, there were either no or minor changes between the thresholds in the interim and the final report released in March 2020. Results are publicly available at https://ec.europa.eu/eusurvey/publication/teg-reporttaxonomy? surveylanguage $=\mathrm{en}$.
} 
around half of which are private individuals. We only consider answers from public or private organisations and companies in our evaluation, i.e. a total number of 355 such stakeholders (see Figure 1).

We follow a two-step procedure in our evaluation of the EU consultation. First, we code the responses on the thresholds proposed for the different activities in the Taxonomy, as well as the answers on the choice of metric. This allows us to assess quantitatively the distribution of responses for each activity in the Taxonomy. In a second step, we perform a qualitative analysis of the answers for selected activities, in order to judge the compatibility of the proposed thresholds with the goal of climate neutrality (section 4). Following this procedure, we carry out an in-depth assessment of a total number of 1672 responses on the different economic activities in the TEG report. ${ }^{3}$

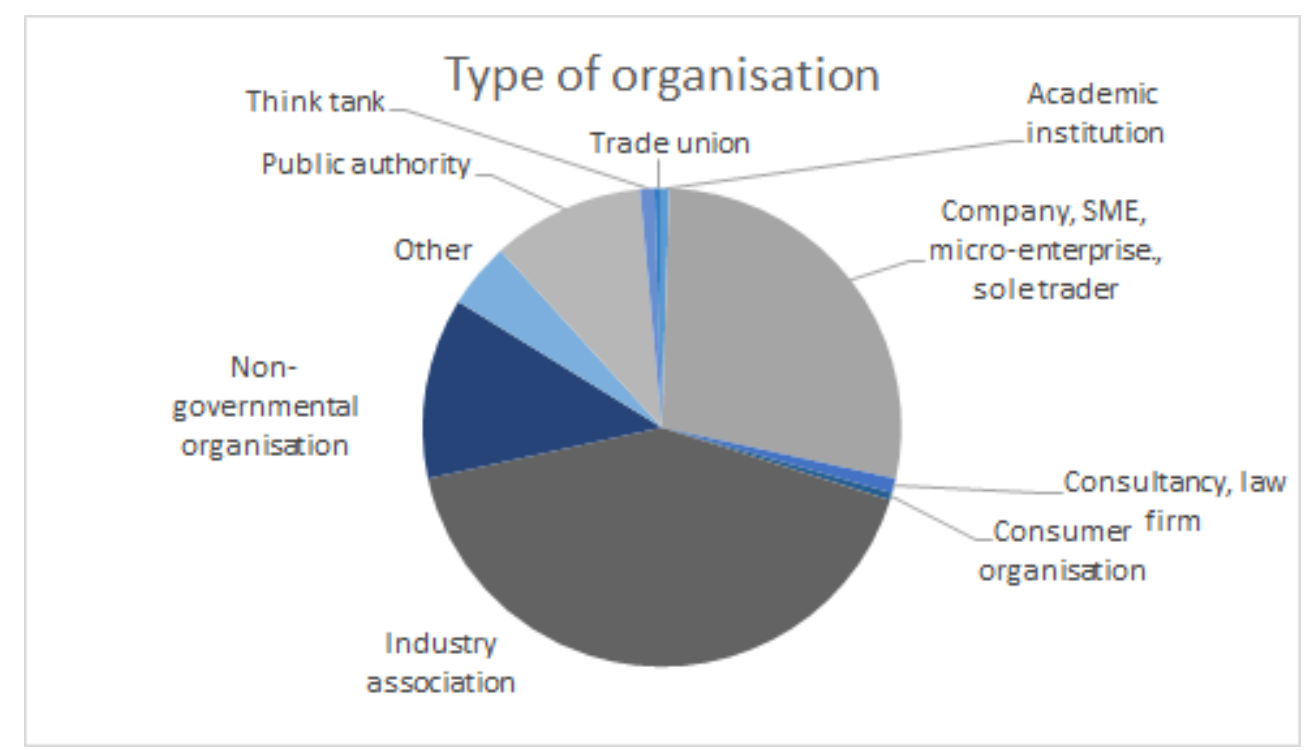

\section{Figure 1: Respondents in the EU consultation}

Total of 355 organisations and 1672 responses.

The overview of respondents shown in Figure 1 indicates a central challenge of our analysis: The distribution of organisations taking part in the EU consultation is not a random draw from all institutions affected by the EU Taxonomy. Instead, depending on the resources available and the interest in the subject, organisations self-select into participating in the consultation. As can be seen from Figure 1, around 70 percent of the respondents are either industry associations or private companies, whereas 12 percent are non-governmental organisations (NGOs). This compares to 50 percent "In-house lobbyists and trade/business/professional associations" and about 25 percent NGOs among the 12,052 registrants in the EU Transparency Register. ${ }^{4}$ Organisations like NGOs were therefore underrepresented in the public consultation. In order to alleviate this challenge, we scrutinise arguments brought forward in the consultation independent of the number of times they were raised in the qualitative part of our assessment, using also additional literature for this purpose.

\footnotetext{
${ }^{3}$ Since many organisations commented on several activities, the total number of responses is higher than the total number of respondents.

4 See https://ec.europa.eu/transparencyregister/public/consultation/statistics.do?action=prepareView\&locale=en\#en (numbers as of 09 November 2020).
} 


\section{Applications and coverage of the Taxonomy}

\subsection{Applications of the Taxonomy}

In principle, there is a multitude of applications for the EU Taxonomy. We differentiate between two basic types of applications of the Taxonomy (Figure 2). The first application is for evaluating the climate performance of specific new investments, such as a new power plant, a new production plant or a new building. Examples are potential applications within EU-level or national-level Covid19recovery packages, the multi-annual financial framework of the EU (MFF) or the European Fund for Strategic Investments (EFSI), which will be replaced by the InvestEU Program from 2021. The relevant metric in the case of new investments is the share of Taxonomy-aligned capital expenditure (capex).

A second application is to evaluate the performance of an individual company or a portfolio, e.g. of power plants, car fleets or buildings. Examples are decisions to invest in a company's equity, an infrastructure fund or a real estate fund, to buy bonds issued by a company, or to provide a loan to a company. The relevant metric in this case is the share of Taxonomy-aligned revenue or operating expenses (opex). The Taxonomy-aligned share of opex might also be relevant to judge if climate targets set by individual companies for their respective institutions can be reached.

Level
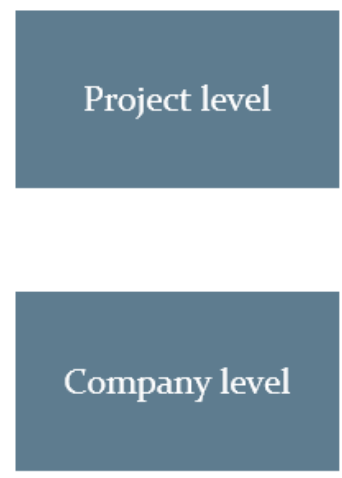

Metric
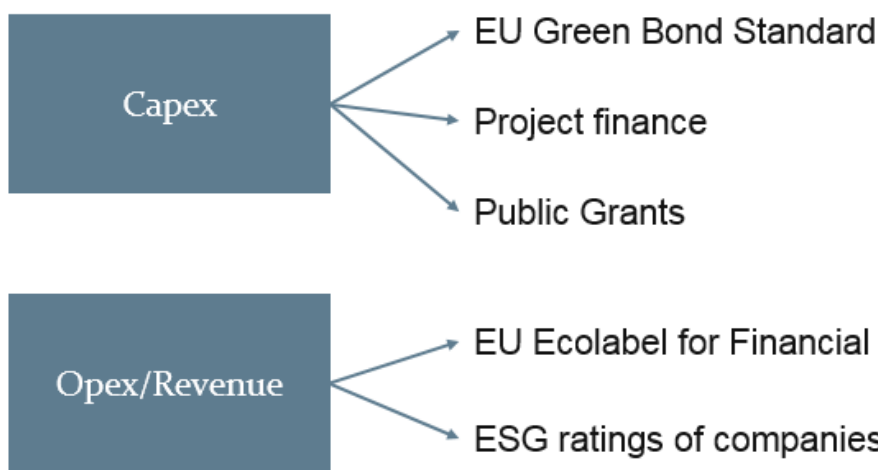

Application

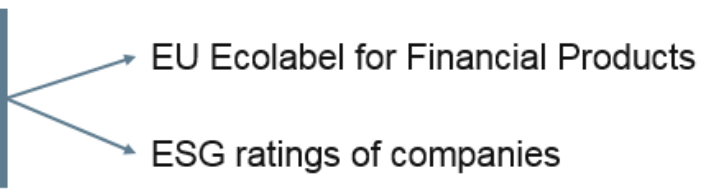

Figure 2: Applications of the Taxonomy

The two different use cases of the Taxonomy may influence capital costs of companies through two channels. First, on the project level, firms that invest into projects in line with the Taxonomy may increasingly benefit from public subsidies via national or EU-wide programmes, such as the KfW loan programme Klimaschutzoffensive für den Mittelstand launched in 2020. Second, on the company level, firms that fare well in terms of the thresholds set by the Taxonomy may benefit from lower costs of debt. One of the reasons may be increased transparency provided by the taxonomy: Research has shown that for companies disclosing their $\mathrm{CO}_{2}$ emissions, more carbon intensive companies have higher costs of debt, and disclosure leads to a significant reduction of emissions (Kleimeier and Viehs, 2018; Downar et al., 2019). Moreover, there may be an increased demand at the stock market for companies with a high share of Taxonomy-aligned activities, as they can be included in sustainable indices and sustainable investment funds. Although the overall evidence on the existence of such a 
green premium is mixed, credibility of green bond standards is a key determinant on whether such a premium exists (Kapraun and Scheins, 2019). The EU Taxonomy can be expected to improve the credibility of green bonds relative to existing green bond standards. Banks using Taxonomy-aligned assets as underlying assets for green bonds may also benefit from more preferential refinancing conditions (Kapraun and Scheins, 2019; Zerbib, 2019).

\subsection{Sectoral coverage and scope of the Taxonomy}

Currently, the Taxonomy covers seven main economic sectors, namely agriculture and forestry, manufacturing, energy (electricity, gas, steam and air-conditioning supply), transport, buildings, water, waste and sewage remediation, and information and communication technologies (ICT). At NACE level $1^{5}$, the Taxonomy covers economic activities within all major greenhouse gas emitting sectors (approximately 90 percent of direct greenhouse gas emissions).

Within these broad economic sectors, not all economic activities are covered by the Taxonomy. For a better estimate of the share of total emissions covered, it is therefore necessary to consider a more refined NACE level classification. With a more granular sectoral focus (at NACE level 2), the share of emissions of the sectors that include economic activities covered by the Taxonomy declines to 80 percent, mainly due to the exclusion of certain transport and manufacturing activities. This is still an upper bound, as not all activities at sub-sector level are covered by the Taxonomy, such as air transport (3.6 percent of direct greenhouse gas emissions)

Interestingly, the sectors addressed by the Taxonomy are responsible for a much lower share of employment and gross value added (GVA) than emissions: The same sectors responsible for threequarters of EU emissions have a share of 20 percent of employment and 28 percent of gross value added at NACE 2 level. Labour intensity is thus not a good indicator for carbon intensity. However, the European non-financial reporting directive (NFRD) makes reporting for non-financial information mandatory for companies with more than 500 employees. Adding taxonomy-related information into the NFRD requirements will therefore add reporting requirements for some companies with low emissions, and exclude other companies with high emissions.

Figure 3 shows the emissions of different economic sectors, as well as their contribution to employment and gross value added. The sectors with the largest share of greenhouse gas emissions are electricity, gas, steam and air conditioning supply (D) with 23 percent of greenhouse gas (GHG) emissions and crop and animal production (A01) with 13 percent of GHG emissions. Transport and heating activities by households (jointly adding almost 20 percent of GHG emissions), which are not defined as economic sectors in the NACE classification, are also among the top four sources of emissions. ${ }^{6}$ Conversely, sectors with a high share of employment and gross value added are typically less emissions-intensive: The sectors with the largest share in employment are wholesale and retail trade $(\mathrm{G})$, human health and social work activities $(\mathrm{Q})$ and education $(\mathrm{P})$. The economic sectors with

\footnotetext{
${ }^{5}$ NACE is the classification of economic activities in the European Union. Level 1 is the first layer of sectors consisting of 21 sectors, indicated by the letters A to U. Level 2 is the second layer of sectors, indicated by two-digit codes from 01 to 99 .

${ }^{6}$ These sectors are indirectly covered by the taxonomy, because transport activities of households are covered via the threshold for the production of passenger cars. Heating activities by households, on the other hand, are covered via the construction and renovation of buildings activities.
} 
the largest share in gross value added are wholesale and retail trade $(\mathrm{G})$, real estate activities $(\mathrm{L})$ and human health and social work activities (Q).

Emissions-intensive sectors currently not covered by the Taxonomy are responsible for $12.4 \%$ of total emissions (4,595 $\left.\mathrm{Mt} \mathrm{CO}_{2} \mathrm{e}\right)$. These sectors include air transport' (H51), manufacture of coke and refined petroleum (C19), wholesale and retail trade $(\mathrm{G})$, mining and quarrying $(\mathrm{B})$, as well as manufacturing of food, beverages and tobacco (C10-C12). 

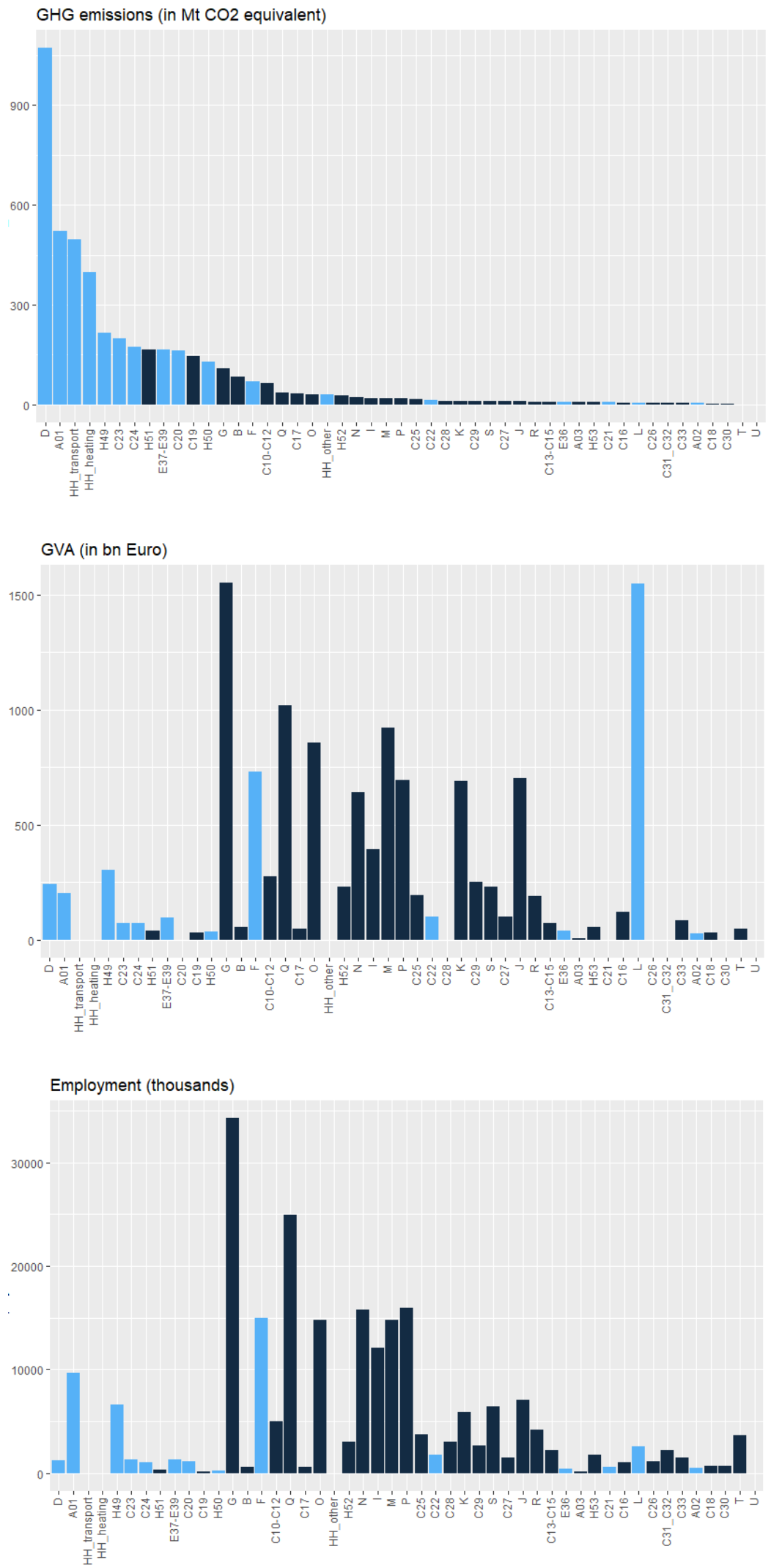

Sectors addressed by the Taxonomy (in light blue): A01 $=$ Crop and animal production

$\mathrm{A} 02=$ Forestry and logging

$\mathrm{C} 20=$ Manufacture of chemicals and chemical products $\mathrm{C} 21=$ Manufacture of basic pharmaceutical products $\mathrm{C} 22=$ Manufacture of rubber and plastic products C23 = Manufacture of other non-metallic mineral products C24 = Manufacture of basic metals

$\mathrm{D}=$ Electricity, gas, steam and air conditioning supply E36 = Water collection, treatment and supply E37 - E39 = Sewerage, waste management, remediation activities

$\mathrm{F}=$ Construction

$\mathrm{H} 49=$ Land transport and transport via pipelines

$\mathrm{H} 50=$ Water transport

$\mathrm{L}=$ Real estate activities

HH_transport $=$ transport activities by households

HH_heating = heating and cooling activities by households

Sectors not addressed by the Taxonomy (in dark blue): A03 $=$ Fishing and aquaculture

$\mathrm{B}=$ Mining and quarrying

$\mathrm{C} 10-\mathrm{C} 12=$ Manufacture of food; beverages and tobacco C13-C15 = Manufacture of textiles, wearing apparel, leather C16 = Manufacture of wood and of products of wood

$\mathrm{C} 17=$ Manufacture of paper and paper products

C18 $=$ Printing and reproduction of recorded media

$\mathrm{C} 19=$ Manufacture of coke and refined petroleum products $\mathrm{C} 25$ = Manufacture of fabricated metal products

$\mathrm{C} 26=$ Manufacture of computer, electronic and optical products

C27 = Manufacture of electrical equipment

C28 = Manufacture of machinery and equipment

$\mathrm{C} 29$ = Manufacture of motor vehicles and trailers

C31-C32 = Manufacture of furniture; other manufacturing

C33 = Repair and installation of machinery and equipment

$\mathrm{C} 30=$ Manufacture of other transport equipment

$\mathrm{G}=$ Wholesale and retail trade

$\mathrm{H} 51=$ Air transport

H52 = Warehousing and support activities for transportation

$\mathrm{H} 53=$ Postal and courier activities

$\mathrm{I}=$ Accommodation and food service activities

$\mathrm{J}=$ Information and communication

$\mathrm{K}=$ Financial and insurance activities

$\mathrm{M}=$ Professional, scientific and technical activities

$\mathrm{N}=$ Administrative and support service activities

$\mathrm{O}=$ Public administration and defence

$\mathrm{P}=$ Education

$\mathrm{Q}=$ Human health and social work activities

$\mathrm{R}=$ Arts, entertainment and recreation

$\mathrm{S}=$ Other service activities

$\mathrm{T}=$ Activities of households as employers

$\mathrm{U}=$ Activities of extraterritorial organisations

\section{Figure 3: GHG Emissions, GVA and employment per NACE sector (level 1 and level 2), EU 2017}

The figure shows 2017 emissions data from Eurostat (in $\mathrm{CO}_{2} \mathrm{e}$ ). Sectors in light blue are (partly) addressed by the Taxonomy, sectors in dark blue are not covered by the Taxonomy. Sectoral emissions are presented at NACE 2 level where available, and at level 1 where no lower level exists (e.g. sectors D and G) or overall emissions of the sector are low. Source: eurostat 


\section{Sustainable finance taxonomy in light of climate neutrality}

The EU has committed to aim for climate neutrality by 2050 (EU, 2020). This commitment is in line with the Paris Agreement: In order to have a reasonable chance of limiting warming to $1.5^{\circ} \mathrm{C}$, global emissions need to reach net zero around mid-century (IPCC, 2018). Based on the performance thresholds in the Taxonomy (see Appendix for an overview), this section relates economic activities to climate neutrality and analyses for selected economic activities whether the performance thresholds set out the Taxonomy are compatible with a pathway towards climate neutrality. We focus on the screening criteria regarding the climate change mitigation target and do not explicitly consider the "do no significant harm criteria" (DNSH) and minimum social safeguards in our analysis. For the purpose of illustration of the basic mechanisms, we analyse three sectors that are responsible for a significant share of greenhouse gas emissions, namely transport (exemplified by passenger cars and commercial vehicles), buildings (buildings renovation and construction of new buildings), as well as the basic materials sector (cement). ${ }^{7}$

\subsection{Classification of economic activities}

The EU Taxonomy defines three types of economic activities, "green", "enabling" and "transition". The first two types either comply with climate neutrality (green) or contribute to this goal indirectly (enabling). For the green activities, this means that if all companies were to use only the technologies or conduct the activities as defined in the Taxonomy, the sector would converge to net zero emissions. The enabling activities, on the other hand, are needed for other sectors to comply with climate neutrality. Finally, the transition activities do not yet comply with climate neutrality: Even if all companies complied with the current threshold, the sector would not be climate neutral. For these sectors, the Taxonomy sets technical performance thresholds that determine whether such an activity can be regarded as sustainable.

Table 1 provides an overview of the different types of economic activities. The activities not covered can be differentiated into those with low climate relevance (where developing thresholds for all the economic activities would be too tedious), and those with high climate relevance (which are relevant to reaching climate neutrality and therefore should be covered). For the economic activities covered by the Taxonomy, Table 1 differentiates between whether such activities need to meet a threshold to comply with the Taxonomy or not. Activities defined as green or enabling are automatically eligible, irrespective of the actual carbon emissions associated to them (though they still need to comply with the DNSH criteria and minimum social safeguards). For transition activities, on the other hand, a threshold or minimum requirement exists that defines whether an activity is regarded as sustainable or not. However, such a threshold is not necessarily compatible with climate neutrality. For some of the transition activities, a second (future) threshold is defined that indicates a pathway towards climate

\footnotetext{
${ }^{7}$ Transport is responsible for 11 percent of EU greenhouse gas emissions (see Figure 3). It is the only major economic sector in the EU where emission are still rising and are above 1990 levels. Direct emissions for the heating of residential buildings alone constitutes nine percent of EU emissions (Figure 3). If indirect emissions (e.g. electricity and district heating) and emissions from the heating of commercial buildings is considered, this share rises significantly - in Germany, direct and indirect emissions of all buildings account for roughly a quarter of total emissions (Stede et al., 2020). The production of basic materials accounts for around 25 percent of global $\mathrm{CO}_{2}$ emissions and 16 percent of European GHG emissions (Neuhoff et al., 2019), of which direct and indirect emissions of cement alone are eight percent of global emissions (Andrew, 2018).
} 
neutrality, while other activities lack such a pathway. In order to illustrate this concept, we assess some of the activities covered by the Taxonomy from those three categories (green/enabling, transition with pathway, transition without pathway) in more detail in the remainder of section 4 .

Table 1: Coverage of Taxonomy and pathway towards climate neutrality

\begin{tabular}{|c|c|c|c|c|c|c|}
\hline \multirow{3}{*}{$\begin{array}{l}\text { Activity: } \\
\text { Example }\end{array}$} & \multicolumn{4}{|c|}{ Covered by Taxonomy } & \multicolumn{2}{|c|}{ Not covered } \\
\hline & \multirow{2}{*}{$\begin{array}{c}\text { Green } \\
\text { Electricity } \\
\text { and heat } \\
\text { from } \\
\text { renewables }\end{array}$} & \multirow{2}{*}{$\begin{array}{c}\text { Enabling } \\
\begin{array}{l}\text { Transmis- } \\
\text { sion, green } \\
\text { IT }\end{array}\end{array}$} & \multicolumn{2}{|c|}{ Transition } & \multirow{2}{*}{$\begin{array}{c}\begin{array}{c}\text { High } \\
\text { climate- } \\
\text { relevance }\end{array} \\
\begin{array}{c}\text { Airlines, } \\
\text { wholesale \& } \\
\text { retail trade }\end{array}\end{array}$} & \multirow{2}{*}{ 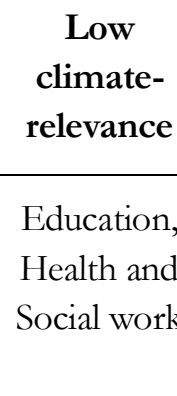 } \\
\hline & & & $\begin{array}{c}\text { Passenger } \\
\text { cars }\end{array}$ & $\begin{array}{c}\text { Basic } \\
\text { materials, } \\
\text { building } \\
\text { retrofits }\end{array}$ & & \\
\hline $\begin{array}{l}\text { Current } \\
\text { threshold }\end{array}$ & & & & & $\begin{array}{l}\text { Threshold } \\
\times \text { missing }\end{array}$ & \\
\hline $\begin{array}{l}\text { Pathway/ } \\
\text { Future } \\
\text { threshold }\end{array}$ & & & & $\times \begin{array}{r}\text { Pathway } \\
\text { missing }\end{array}$ & $X_{\text {missing }}^{\text {Threshold }}$ & \\
\hline
\end{tabular}

\subsection{Green/Enabling}

Green and enabling activities can be found in all of the seven sectors addressed by the Taxonomy. All of these activities cause few or no $\mathrm{CO}_{2}$ emissions, capture $\mathrm{CO}_{2}$ from the atmosphere or help to reduce emissions in other sectors.

In the agriculture sector, afforestation and reforestation are classified as green activities, as trees capture $\mathrm{CO}_{2}$ from the atmosphere and hence reduce $\mathrm{CO}_{2}$ emissions. In the manufacturing sector, only manufacturing of low-carbon technologies is classified as a green activity. All other manufacturing sub-sectors are classified as "transition activities" (see next section). Within the energy sector, the production of electricity from solar, wind and ocean energy as well as the transmission, distribution and storage of electricity, thermal energy and hydrogen and the utilization of waste heat is classified as green activity. In the water, sewage and waste sector, eligible activities are anaerobic digestion or composting of sewage sludge or bio-waste, capture and utilization of landfill gas and $\mathrm{CO}_{2}$ and the transport of $\mathrm{CO}_{2}$.

The activity "manufacture of low-carbon technologies" is a special case, as it does not correspond to one economic sector (NACE) but to several different sectors. Instead, it contains a list of technologies which are regarded as low-carbon technologies but does not have a specific $\mathrm{CO}_{2}$ threshold. It includes components and technologies for (eligible) renewable energy technologies, for vehicles with low or zero tailpipe emissions, for electric appliances rated in the highest energy efficiency class and for energy efficient equipment for buildings. In principal, any technology can be 
added to the list, if it shows substantial emission reductions. The advantage is that it allows for the inclusion of new technologies as they emerge. The disadvantage is that it also allows for lobbying by certain industry associations. This is reflected by the high number of 77 public and private organizations from various industries (energy, transport, manufacturing, buildings) that responded to the public consultation, much more than for most other sectors

\subsection{Transition: Threshold with pathway towards climate neutrality}

For some activities two thresholds were defined, one current threshold and one future threshold. In these cases, the future threshold typically indicates a pathway towards climate neutrality for these activities. An example for such activities in the energy sector is the production of electricity from gas, bioenergy, hydropower and geothermal energy. For these activities, life cycle emissions (LCE) need to be below $100 \mathrm{~g} \mathrm{CO}_{2} / \mathrm{kWh}$ (today) and need to decline to zero by $2050^{8}$. In this section, we look at more detail at passenger cars and commercial vehicles.

For passenger cars, the performance thresholds are in line with the EU's Clean Vehicles Directive (2019/1161). Accordingly, all zero tailpipe emission vehicles (incl. hydrogen, fuel cell, electric) are eligible, irrespective of the carbon intensity of the fuel they consume. Cars with tailpipe emission intensity of $\max 50 \mathrm{~g} \mathrm{CO}_{2} / \mathrm{km}$ (vehicle $\mathrm{km}$ ) are eligible until 2025. 'The underlying rationale is that the energy carriers used are assumed to become low or zero carbon "in the near future" (TEG, 2020b)..$^{10}$ The threshold of $50 \mathrm{~g} \mathrm{CO}_{2} / \mathrm{km}$ until 2025 is around $50 \%$ of the current fleet emissions performance standards of $95 \mathrm{~g} \mathrm{CO} / \mathrm{km}$ for passenger cars (Directive 2019/631). ${ }^{11}$ In practice, this excludes many current plug-in hybrids from the Taxonomy, since only smaller plug-in hybrid models can meet this threshold (UBA, 2019).

In the stakeholder consultation, a split between industry respondents (associations and individual companies) versus NGOs and environmental agencies can be observed. While NGOs and environmental agencies mostly agreed that the thresholds were compatible with net-zero emissions, industry representatives took a more critical stance: A typical criticism was to make the zero emission vehicle standard mandatory by 2030 instead of 2025, i.e. to extend the interim period where lowemission combustion vehicles are admissible. Thus, almost 40 percent of respondents argued for a less stringent threshold. This is not surprising as the responses for passenger cars were dominated by companies (38 percent of respondents) and industry associations (one-third of respondents).

\footnotetext{
8 The explicit reference to a declining value to zero by 2050 has been removed in the draft of the Delegated Acts (European Commission, 2020b).

${ }^{9}$ In contrast to passenger cars, the rest of the transport sector has no clear pathway: Many of the thresholds will be reviewed in 2025, either because relevant European directives are reviewed (such as the freight transport services by road), or because the technology for zero-emission vehicles is not yet commercially available (e.g. interurban scheduled road transport, see TEG, 2020b).

${ }^{10}$ This assumption is more justified for vehicles powered by electricity, as renewable electricity is expanded across Europe, leading to a declining carbon intensity of electricity). Hydrogen may also be produced by electricity through electrolysis ('green' hydrogen), however it may also be produced from natural gas via steam reforming ('grey' hydrogen), which is far more emissions-intensive.

${ }^{11}$ In practice, the difference is even larger, since the Taxonomy threshold is based on the Worldwide Harmonised Light Vehicles Test procedure (WLTP), while Directive 2019/631 foresees a replacement of the fleet performance thresholds (which were so far based on the New European Test Cycle, NEDC) for 2021. It is expected that the maximum fleet emissions under Directive 2019/631 will rise by around 20 percent under WLTP (BMU, 2020).
} 
Another commonly voiced suggestion by manufacturers was to change the metric to life-cycle emissions or well-to-wheel instead of tailpipe emissions.

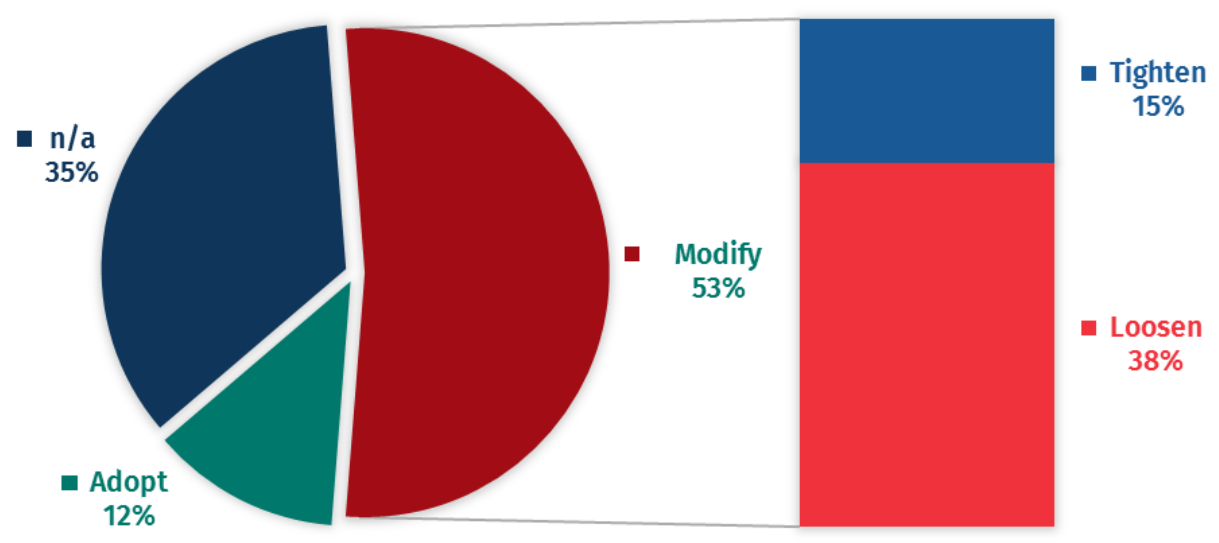

Figure 4: Perspectives on the threshold for passenger cars and commercial vehicles $\mathrm{n}=40$ respondents.

The passenger cars sector illustrates the difficulty of using a single threshold for different purposes (cf. section 3.1). While on the company level of a car manufacturer, an average emissions intensity of the fleet of $50 \mathrm{~g} \mathrm{CO}_{2} / \mathrm{km}$ would already be quite ambitious, on a project level an investment into less efficient vehicles (e.g. a new factory producing hybrid cars) may not be necessary from a climate point of view, since zero tailpipe emissions vehicles are already commercially available.

\subsection{Transition: Threshold without pathway towards climate neutrality}

In several sectors, activities exist where only one performance threshold was defined, which does not indicate a pathway towards climate neutrality. In this section, we look at two prominent examples, namely buildings (section 4.4.1) and manufacturing of basic materials (section 4.4.2).

\subsubsection{Buildings}

We assess the thresholds both for new buildings and retrofits. For either of these activities, the standards for compliance with the Taxonomy differ based on the location of the building.

\section{$\underline{\text { Building renovation }}$}

For renovations of existing buildings, there are two ways how an activity can comply with the Taxonomy. First, any 'major renovation', according to the Energy Performance of Buildings Directive (EPBD, 2010/31/EU), qualifies as Taxonomy-compatible. Second, any renovation that reduces energy consumption by at least 30 percent is also eligible under the Taxonomy. This needs to be verified by an energy audit and an energy performance certificate (European Commission, 2020b).

The definition of a major renovation varies between EU countries. It is either defined relative to the building value (costs of the renovation exceed 25 percent of the building value) or relative to the building surface (more than 25 percent of the surface of the building envelope undergoes renovation). 
Depending on the national efficiency of the building stock, these criteria are estimated to translate into a reduction of final energy demand of 50 to 80 percent (Toleikyte et al., 2016). Consequently, the Taxonomy's second criterion of reducing energy demand by at least 30 percent can be seen as the 'weaker' criterion (i.e. more easily to fulfil).

Depending on the previous renovation status of a building, reducing energy consumption by 30 percent does not necessarily make a building compatible with a climate-neutral building stock. ${ }^{12}$ This would holds for a large share of European buildings: In those European countries, where data from energy performance certificates (EPCs) is available, only three percent of buildings have the highest energy performance class (BPIE, 2017). In Germany, residential dwellings with more than one flat consume around $130 \mathrm{kWh} / \mathrm{m}^{2}$ annually (temperature-adjusted), corresponding to an energy efficiency class of D to E (Stede et al., 2020). For these buildings, a reduction of more than 60 percent would be required to reach Germany's efficiency class A, while a 30 percent reduction of energy consumption would leave such dwellings still in the mid-range of the energy efficiency class C. ${ }^{13}$

In the stakeholder consultation, one of the most frequent critiques was that there is no absolute energy efficiency goal as part of the buildings renovation threshold. Such a threshold could, for example, relate to the energy efficiency classes set in the energy performance certificates. The thresholds of the EPC classes (e.g. classes A to G) vary between EU countries and thus reflect different climatic conditions or national preferences for efficiency standards, which would make them a viable option. Another critique was that no ex-post metering is required, reflecting concerns that building retrofits sometimes do not deliver the promised savings (e.g. Fowlie et al., 2018). In total, half of the stakeholders responding to the buildings renovation threshold propose a tightening of the renovation threshold (Figure 5). This is especially interesting since two-thirds of the respondents in this section are companies or industry associations, which reflects that there are also corporate stakeholders with an interest in higher efficiency goals.

\footnotetext{
${ }^{12}$ In a recent study for the European Commission, renovations that reduce energy consumption are on the margin of "light" renovations (Ipsos and Navigant, 2019)

${ }^{13}$ In Germany, buildings with a consumption of $75-100 \mathrm{kWh} / \mathrm{m}^{2}$ a are labelled as energy efficiency class C. Any consumption below $50 \mathrm{kWh} / \mathrm{m}^{2}$ a belongs to class A, buildings with a consumption below $30 \mathrm{kWh} / \mathrm{m}^{2}$ a are labelled class $\mathrm{A}+$.
} 


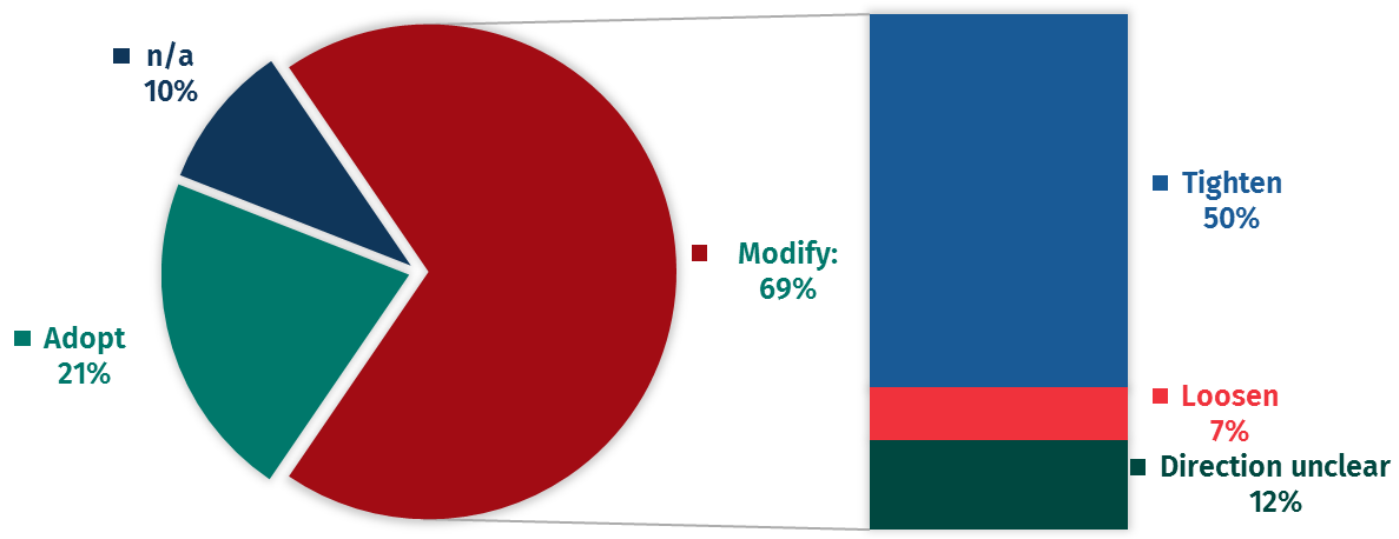

Figure 5: Perspectives on the buildings renovation threshold $\mathrm{n}=42$ respondents.

\section{Construction of new buildings}

For the construction of new buildings, the annual primary energy demand (in $\mathrm{kWh} / \mathrm{m}^{2}$ ) must be 20 percent lower than the national 'nearly zero-energy buildings' (NZEB) standard. This lower demand can be achieved either by technical efficiency standards, or by the installation of on-site renewables. ${ }^{14}$ According to the Energy Performance of Buildings Directive, all newly constructed buildings in the EU must be NZEBs from 2021. However, these NZEB standards are determined nationally. Although this is sensible in principle due to different climatic conditions among Member States, in practice there is a very high variation of the NZEB thresholds: While Denmark has the most stringent standard of all EU countries $\left(20 \mathrm{kWh} / \mathrm{m}^{2} \mathrm{a}\right)$, this maximum primary energy requirement rises to more than $100 \mathrm{kWh} / \mathrm{m}^{2} \mathrm{a}$ in countries such as France (Ipsos and Navigant, 2019). Consequently, several respondents suggest to solve this issue by introducing an additional panEuropean maximum eligible consumption level for new buildings. This would address the perverse incentive that some investors might invest in countries with lower standards to green their portfolios. Other critiques included that fossil fuel consumption is not ruled out for new buildings, and that (similarly as for building retrofits) actual consumption should be metered.

\subsubsection{Manufacture of basic materials}

With the exception of the manufacture of low-carbon technologies discussed in section 4.2, all manufacturing activities included in the Taxonomy belong to the basic materials sector. Typically, the threshold corresponds to the value of EU ETS benchmarks (in tonne $\mathrm{CO}_{2} \mathrm{e} /$ tonne material), which determine the level of free allocations based on the performance of the best-performing plants. ${ }^{15}$ Here, we analyse the manufacture of cement in more detail, due to its central importance in global climate policy: Direct and indirect emissions of the manufacture of cement alone are responsible for eight percent of global emissions (Andrew, 2018).

\footnotetext{
${ }^{14}$ Any off-site energy generation must be limited to district heating and cooling systems and local renewable energy sources (TEG, 2020b).

15 The manufacture of hydrogen is an exception to this rule. It is set at $5.8 \mathrm{tCO} e / t$ of hydrogen, while the ETS benchmark is at $8.85 \mathrm{tCO}_{2} \mathrm{e}$.
} 
EU ETS benchmarks rely on best available technology (BAT) estimates calculated from historic production data from 2007 to 2008. NGOs and public authorities in particular emphasised that the benchmarks are outdated and do not take into account technological progress during the last decade. ${ }^{16}$ The clinker threshold of $0.766 \mathrm{tCO}_{2 \mathrm{e}} / \mathrm{t}$ of clinker was criticised, since studies show that a threshold of 0.7 would be realistic (Favier et al., 2018). This criticism is reflected in a high number of respondents that propose to tighten the threshold for the cement sector (Figure 6).

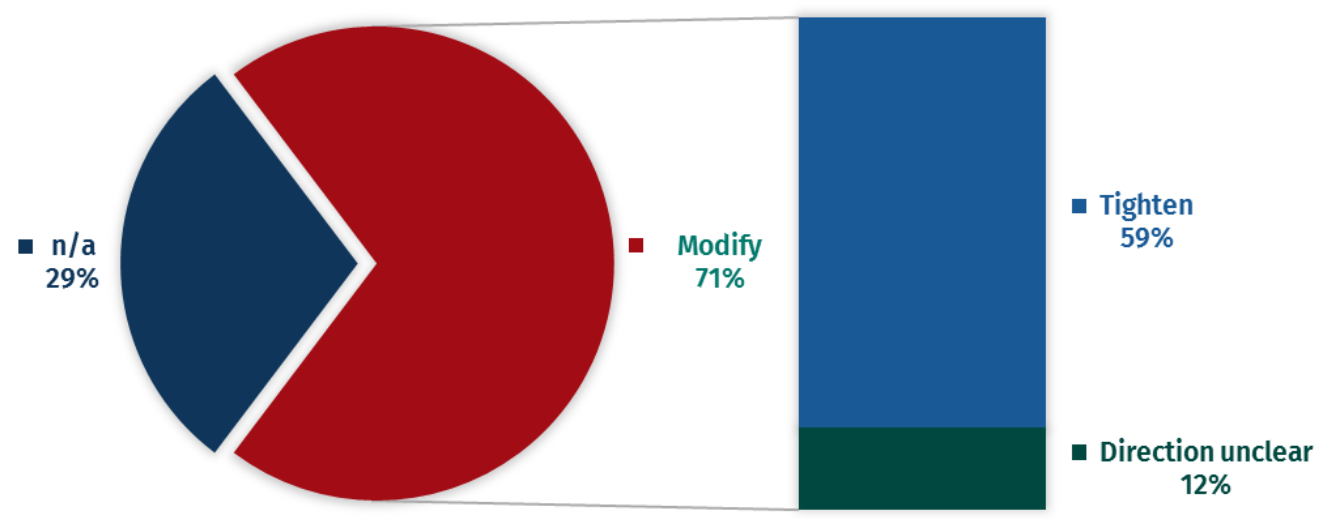

Figure 6: Perspectives on the threshold for the cement sector

$\mathrm{n}=17$ respondents.

Another highly disputed performance threshold is the benchmark for cement, which is based on a multiplication of the clinker threshold with the global average clinker to cement ratio of 65 percent (share of clinker used in the production of cement). Since for the cement sector an average determines the threshold in the Taxonomy (instead of a metric based on the best-performing installations), this approach is criticised as inconsistent with the BAT approach chosen for the other basic materials by some respondents. Moreover, several respondents cite a report from the United Nations Environmental Program, which regards a global average clinker to cement ratio of 60 percent on average as realistic (up to 50 percent in some applications), due to substitution effects (Scrivener et al., 2018; Rissman et al., 2020). As a comparison, the current ratio in European production is at roughly 80 percent, and the European cement industry association predicts 70 percent for 2050 (CEMBUREAU, 2018). Two national environmental agencies (Germany and Austria) question if cement should be part of the Taxonomy of sustainable activities at all (since fully decarbonised cement is currently not commercially available) and refer to the missing focus on the possibility to substitute some types of the basic material. ${ }^{17}$ The Austrian environmental agency points out that the cement sector is similar to the hydrogen sector with respect to having to mitigate emissions by technologies that are not yet commercially available. However, while the hydrogen threshold is set below the ETS benchmark, the threshold for the manufacture of cement is set at $100 \%$ of the EU ETS benchmark value. This discrepancy may be explained by different applications of the Taxonomy

\footnotetext{
${ }^{16}$ The EU has also acknowledged the need for more frequent updates of these benchmarks, which will be updated twice in the years 2021-2030 (phase 4 of the EU ETS), in order to avoid windfall profits and reflect technological developments since 2008. https://ec.europa.eu/clima/policies/ets/revision_en (accessed 12 November 2020).

${ }_{17}$ Approximately two-thirds of the emissions from the cement production stem from process emissions during the clinker production (decomposition of limestone), with the remainder of $\mathrm{CO}_{2}$ emissions being due to combustion of fuels. These emissions can only be fully avoided by carbon capture and storage or use, although they can be partly offset by substituting clinker by other mineral components in cement and concrete (IEA, 2018; Neuhoff et al., 2014).
} 
(see discussion in section 3.1): While there are significant existing cement production capacities (for which the Taxonomy threshold will apply also at company level), the hydrogen threshold will mostly be relevant for greenfield investment into new production capacity.

\section{Discussion and conclusion}

The EU Taxonomy for sustainable activities is a tool that may play an important role in channelling investments into low-carbon activities in the economy, thus helping to put the EU climate targets into practice. With its focus on sectors that have a high carbon intensity, we demonstrate that the Taxonomy currently covers economic activities in sectors that are responsible for up to 80 percent of the EU's emissions, but only 20 percent of employment and 28 percent of gross value added. While the Taxonomy is still under development, this paper identifies a number of important lessons learned and points out areas for further development.

First, labour-intensity is not a good indicator for carbon-intensity. However, under the European non-financial reporting directive (NFRD) all companies with more than 500 employees need to report non-financial information. Adding taxonomy-related information into NFRD requirements will therefore exclude some emission-intensive companies, while at the same time adding administrative effort for companies with low emissions. To circumvent this issue, an additional metric based on emission-intensity could be added as a requirement for Taxonomy-related reporting under NFRD.

Second, the Taxonomy does not currently indicate a path towards climate neutrality for several of the economic activities it covers. While activities labelled 'green' or 'enabling' are assumed to contribute directly to reaching the climate goals, for the sectors in 'transition' technical thresholds need to be met for an activity to be Taxonomy-eligible. We show that pathways towards climate neutrality are set out for some of these activities, such as passenger cars, where only fully electric zero-tailpipe emission vehicles are eligible from 2026. However, in other sectors such a pathway does not exist, most notably in building renovation and the basic materials sector (e.g. steel or cement). Both are responsible for a major share of emissions. In these sectors, the thresholds are based on current best available technology. However, typically capital-intensive breakthrough technologies are needed to decarbonise these economic activities. These innovative technologies are currently not incentivised by the Taxonomy.

Third, some of the challenges relating to setting adequate performance criteria can be understood by the variety of possible use cases of the Taxonomy. We differentiate between the company level (share of Taxonomy-compatible revenues), where the Taxonomy may be used for evaluating the current average performance of companies, and the project level, where the Taxonomy may be used as a screening tool for new investments. This dichotomy illustrates the dilemma of using one performance threshold for different purposes: In the basic materials sector, for example, basing the eligibility threshold on the best-performing installations using conventional technology may be sensible when the Taxonomy is used to evaluate the existing activities of a company. However, for new investments, only investments into innovative technologies that go beyond the status quo should be incentivised. The dilemma of having a single criterion for multiple purposes may persist for 
sectors in need of investments into breakthrough technologies, even if the thresholds for Taxonomyeligible activities become more stringent over time.

The challenge of using a single criterion for multiple purposes creates the risk that the Taxonomy will incentivise only marginal improvements for new investments, which might create a lock-in into carbon-intensive assets and hinder innovation in the long-term (Mattauch et al., 2015; Unruh, 2000). It can be solved in two ways in principle. First, multiple thresholds could be defined for a given economic activity, differentiating between investments in newly built projects on the one hand and existing assets at the company level on the other hand. This spirit is already embodied in the various thresholds for buildings-related activities, where criteria for the construction of new buildings are more stringent than those for existing buildings (retrofits, as well as acquisition and ownership of real estate). Second, additional forward-looking indicators, such as a decarbonisation strategy, climate targets or green investment targets, can be implemented in order to identify companies that plan to comply with climate neutrality in the future (Monasterolo, 2020).

Finally, although a large fraction of overall EU emissions are addressed by the Taxonomy, many economic activities are not covered by the system. These non-covered activities can be divided into three broad categories. First, economic activities which account for a large fraction of gross value added and employment, but for a small share of overall emissions. Excluding these economic activities minimises administrative effort for sectors where emissions reductions are less important in terms of the overall mitigation potential. Second, economic activities which are carbon-intensive, but which cannot be fully substituted and where technological progress is needed to reduce emissions in the future, such as aviation and maritime shipping. For these activities, thresholds should be developed. Third, economic activities that are carbon-intensive but should be phased out since technological alternatives exist, such as the burning of coal and petroleum.

For the third group of activities that are incompatible with a climate-neutral economy, an explicit socalled "brown taxonomy" should be developed. Such an explicit exclusion list could build on the "do no significant harm" (DNSH) criteria of the Taxonomy. It would be a valuable screening tool for sustainable investment funds (e.g. as defined under the EU Ecolabel Directive), as well as governmental subsidies or investments. A brown taxonomy would create the possibility to explicitly rule out investments into activities deemed unsustainable, while still allowing investments into activities not covered due to their low emissions intensity. It would also provide transparency to investors about the risk of potential "stranded assets" in their portfolios. 


\section{Acknowledgements}

The authors acknowledge funding from the Mercator Foundation via the project 'Rahmenprogramm Sustainable Finance' (grant number 19026202) and the German Federal Ministry for the Environment (FKZ UM19145150). We thank Karsten Neuhoff for helpful comments and suggestions. We also thank Marc Blauert, Katharina Erdmann and Lucie Bioret for excellent research assistance. 


\section{References}

Andrew, R.M., 2018. Global CO2 emissions from cement production. Earth Syst. Sci. Data 10, 195-217. doi:https://doi.org/10.5194/essd-10-195-2018

BMU, 2020. Das System der CO2-Flottengrenzwerte für Pkw und leichte Nutzfahrzeuge. Federal Ministry for Environment, Nature Conservation and Nuclear Safety.

BPIE, 2017. 97\% of buildings in the EU need to be upgraded. Factsheet. Buildings Performance Institute Europe.

CEMBUREAU, 2018. Building carbon neutrality in Europe. Engaging for concrete solutions.

Cho, S.Y., Lee, C., Pfeiffer, R., 2013. Corporate social responsibility performance and information asymmetry. doi:10.1016/J.JACCPUBPOL.2012.10.005

Dhaliwal, D.S., Radhakrishnan, S., Tsang, A., Yang, Y.G., 2012. Nonfinancial Disclosure and Analyst Forecast Accuracy: International Evidence on Corporate Social Responsibility Disclosure. Account. Rev. 87, 723-759. doi:10.2308/accr-10218

Downar, B., Ernstberger, J., Rettenbacher, H., Schwenen, S., Zaklan, A., 2019. Fighting Climate Change with Disclosure? The Real Effects of Mandatory Greenhouse Gas Emission Disclosure (DIW Discussion Paper No. 1795). doi:10.2139/ssrn.3352390

EIB, 2020. EIB Group Climate Bank Roadmap 2021-2025. European Investment Bank.

EU, 2020. Long-term low greenhouse gas emission development strategy of the European Union and its Member States. Submission by Croatia and the European Commission on behalf of the European Union and its Member States.

European Commission, 2020a. Stepping up Europe's 2030 climate ambition - Investing in a climate-neutral future for the benefit of our people (COMMISSION STAFF WORKING DOCUMENT- IMPACT ASSESSMENT No. SWD(2020) 176 final).

European Commission, 2020b. Annex 1 to the Draft Delegated Act (Ares(2020)6979284).

European Commission, 2018a. A Clean Planet for all A European strategic long-term vision for a prosperous, modern, competitive and climate neutral economy- In-depth analysis in support on the COM(2018) 773 (No. COM(2018) 773 final).

European Commission, 2018b. Action Plan: Financing Sustainable Growth (No. COM(2018) 97 final).

Favier, A., De Wolf, C., Scrivener, K., Habert, G., 2018. A sustainable future for the European Cement and Concrete Industry. ETH Zürich / EPFL.

FNG, 2020. Marktbericht Nachhaltige Geldanlagen - Deutschland, Österreich und die Schweiz. Forum Nachhaltige Geldanlagen.

Fowlie, M., Greenstone, M., Wolfram, C., 2018. Do Energy Efficiency Investments Deliver? Evidence from the Weatherization Assistance Program. Q. J. Econ. 133, 1597-1644. doi:10.1093/qje/qjy005

Hahn, R., Reimsbach, D., Schiemann, F., 2015. Organizations, Climate Change, and Transparency: Reviewing the Literature on Carbon Disclosure (SSRN Scholarly Paper No. ID 2569525). Social Science Research Network, Rochester, NY.

Hessenius, M., Dumrose, M., Anselm, C., Berendsen, S., Jürgens, I., Klein, C., Koch, F., Löffler, K., Rink, S., 2020. Testing Draft EU Ecolabel Criteria on UCITS equity funds (Report for the European Commission, DG FISMA).

IEA, 2018. Technology Roadmap: Low-Carbon Transition in the Cement Industry. International Energy Agency / Cement Sustainability Initiative.

IPCC, 2018. Summary for Policymakers, in: Masson-Delmotte, V., et al. (Eds.), Global Warming of $1.5^{\circ} \mathrm{C}$. An IPCC Special Report on the Impacts of Global Warming of $1.5^{\circ} \mathrm{C}$ above Pre-Industrial Levels and Related Global Greenhouse Gas Emission Pathways, in the Context of Strengthening the Global Response to the Threat of Climate Change, Sustainable Development, and Efforts to Eradicate Poverty. In press.

Ipsos, Navigant, 2019. Comprehensive study of building energy renovation activities and the uptake of nearly zero-energy buildings in the EU (Final report prepared for the European Commission, DirectorateGeneral for Energy).

IRENA, 2017. Perspectives for the energy transition: Investment needs for a low-carbon energy system.

Kapraun, J., Scheins, C., 2019. (In)-Credibly Green: Which Bonds Trade at a Green Bond Premium? (SSRN Scholarly Paper No. ID 3347337). Social Science Research Network, Rochester, NY. doi:10.2139/ssrn.3347337

Kleimeier, S., Viehs, M., 2018. Carbon disclosure, emission levels, and the cost of debt. 
Mattauch, L., Creutzig, F., Edenhofer, O., 2015. Avoiding carbon lock-in: policy options for advancing structural change. Econ. Model. 50, 49-63.

McCollum, D.L., Zhou, W., Bertram, C., de Boer, H.-S., Bosetti, V., Busch, S., Després, J., Drouet, L., Emmerling, J., Fay, M., Fricko, O., Fujimori, S., Gidden, M., Harmsen, M., Huppmann, D., Iyer, G., Krey, V., Kriegler, E., Nicolas, C., Pachauri, S., Parkinson, S., Poblete-Cazenave, M., Rafaj, P., Rao, N., Rozenberg, J., Schmitz, A., Schoepp, W., van Vuuren, D., Riahi, K., 2018. Energy investment needs for fulfilling the Paris Agreement and achieving the Sustainable Development Goals. Nat. Energy 3, 589-599. doi:10.1038/s41560-018-0179-z

Monasterolo, I., 2020. Climate Change and the Financial System. Annu. Rev. Resour. Econ. 12, 22.1-22.22. doi:10.1146/annurev-resource-110119- 031134

Neuhoff, K., Chiappinelli, O., Gerres, T., Haussner, M., Ismer, R., May, N., Pirlot, A., Richstein, J., 2019. Building blocks for a climate-neutral European industrial sector. Climate Strategies.

Neuhoff, K., Vanderborght, B., Ancygier, A., Atasoy, A.T., Haussner, M., Ismer, R., Mack, B., Martin, R., Ponssard, J.-P., others, 2014. Carbon Control and Competitiveness Post 2020: The Cement Report. Climate Strategies.

Rissman, J., Bataille, C., Masanet, E., Aden, N., Morrow, W.R., Zhou, N., Elliott, N., Dell, R., Heeren, N., Huckestein, B., Cresko, J., Miller, S.A., Roy, J., Fennell, P., Cremmins, B., Koch Blank, T., Hone, D., Williams, E.D., de la Rue du Can, S., Sisson, B., Williams, M., Katzenberger, J., Burtraw, D., Sethi, G., Ping, H., Danielson, D., Lu, H., Lorber, T., Dinkel, J., Helseth, J., 2020. Technologies and policies to decarbonize global industry: Review and assessment of mitigation drivers through 2070. Appl. Energy 266, 114848. doi:10.1016/j.apenergy.2020.114848

Scrivener, K.L., John, V.M., Gartner, E.M., 2018. Eco-efficient cements: Potential economically viable solutions for a low-CO2 cement-based materials industry. Cem. Concr. Res. 114, 2-26. doi:10.1016/j.cemconres.2018.03.015

Stede, J., Schütze, F., Wietschel, J., 2020. Wärmemonitor 2019: Klimaziele bei Wohngebäuden trotz sinkender CO2-Emissionen derzeit außer Reichweite (DIW Wochenbericht 40 / 2020). DIW Berlin.

Sweatman, P., Hessenius, M., 2020. “Applying the EU Taxonomy”: Lessons from the Front Line.

TEG, 2020a. Taxonomy: Final report of the Technical Expert Group on Sustainable Finance (March 2020). Technical Expert Group on Sustainable Finance.

TEG, 2020b. Taxonomy Report: Technical Annex (March 2020). Technical Expert Group on Sustainable Finance.

TEG, 2019. Taxonomy Technical Report (June 2019). Technical Expert Group on Sustainable Finance.

Toleikyte, A., Kranzl, L., Bointner, R., Bean, F., Cipriano, J., De Groote, M., Hermelink, A., Klinski, M., Kretschmer, D., Lapilonne, B., others, 2016. ZEBRA 2020-Nearly zero-energy building strategy 2020. Strategies for a nearly Zero-Energy Building market transition in the European Union. ZEBRA 2020.

UBA, 2019. Ermittlung der Schadstoff- und Klimagasemissionen von Pkw und leichten Nutzfahrzeugen durch WLTP und RDE unter Berücksichtigung zukünftiger Kraftstoffe und Antriebskonzepte (Texte No. 27/2019). German Environment Agency.

Unruh, G.C., 2000. Understanding carbon lock-in. Energy Policy 28, 817-830.

Zerbib, O.D., 2019. The effect of pro-environmental preferences on bond prices: Evidence from green bonds. J. Bank. Finance 98, 39-60. doi:10.1016/j.jbankfin.2018.10.012 
Appendix: Comparison of technical screening criteria in the Taxonomy

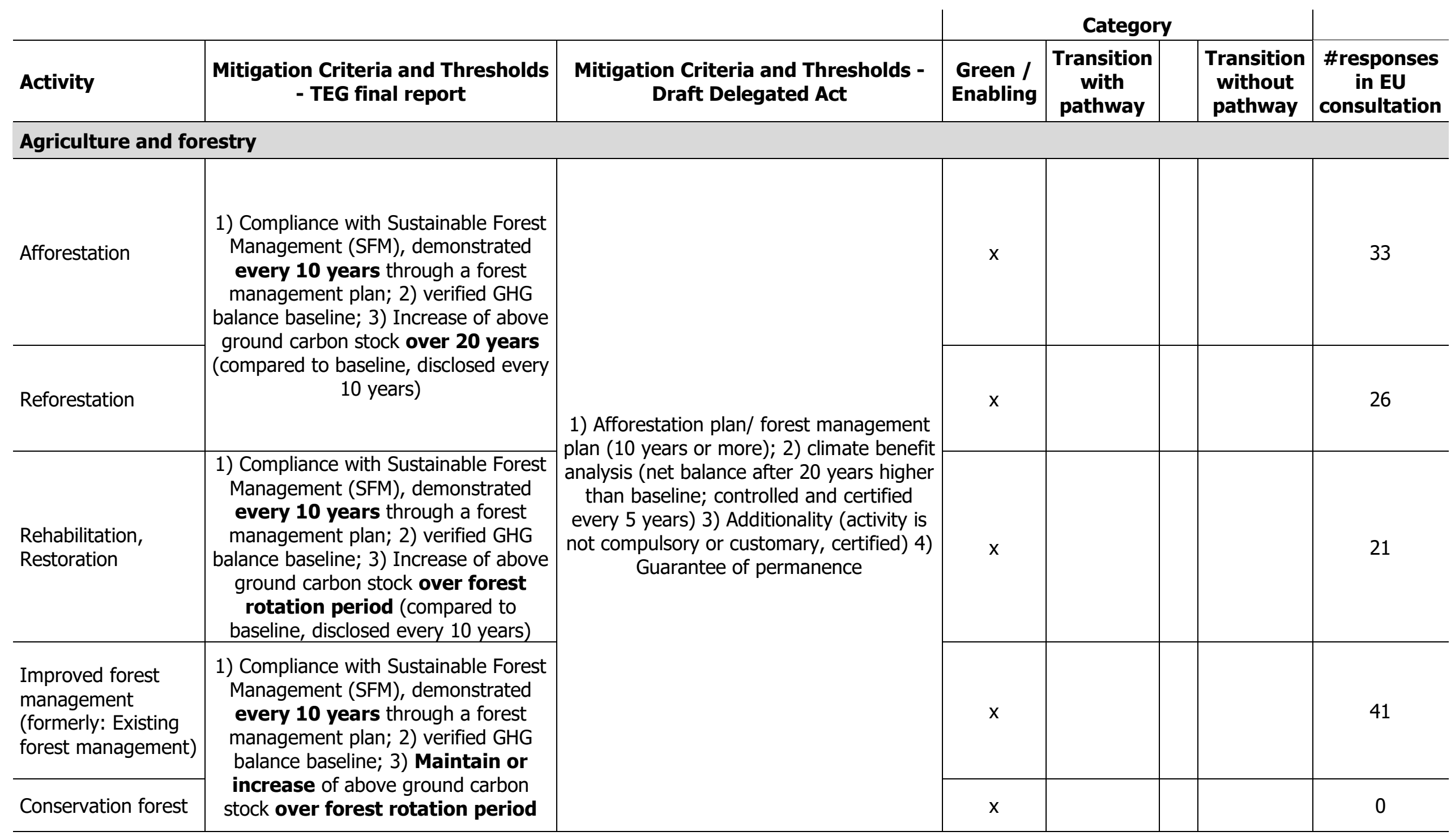




\begin{tabular}{|c|c|c|c|c|c|}
\hline & $\begin{array}{c}\text { (compared to baseline, disclosed every } \\
10 \text { years) }\end{array}$ & & & & \\
\hline $\begin{array}{l}\text { Growing of } \\
\text { perennial crops }\end{array}$ & \multirow{3}{*}{$\begin{array}{c}\text { 1) Avoid or reduce } 2020 \mathrm{GHG} \\
\text { emissions (trajectory: } 20 \% \text { by } 2030 \text {, } \\
30 \% \text { by } 2040 \text { vs. } 2020 \text { ) through a } \\
\text { farm sustainability management } \\
\text { plan; } 2 \text { ) maintain or increase above } \\
\text { and below carbon stock over } 20 \text { years } \\
\text { (audited); 3) no production on } \\
\text { protected land (wetland, forests, } \\
\text { peatland) }\end{array}$} & \multirow{3}{*}{$\begin{array}{l}\text { 1) protection of non-agricultural land } \\
\text { (wetlands, forests, peatland), permanent } \\
\text { grassland is maintained 2) A Farm } \\
\text { Sustainability Plan sets out the strategy } \\
\text { to contribute to climate change mitigation } \\
\text { by a) reducing greenhouse gases (GHG) } \\
\text { emissions and b) strengthening land } \\
\text { carbon sinks 3) compliance with essential } \\
\text { management practices 4) farm records: } \\
\text { yearly record of climate performance 5) } \\
\text { third party verification of Farm } \\
\text { Sustainability Plan and yearly records (at } \\
\text { start and every three years thereafter) }\end{array}$} & & $x$ & 30 \\
\hline $\begin{array}{l}\text { Growing of non- } \\
\text { perennial crops }\end{array}$ & & & & $x$ & 29 \\
\hline Livestock production & & & & $x$ & 29 \\
\hline $\begin{array}{l}\text { Restoration of } \\
\text { wetlands }\end{array}$ & not included in TEG report & $\begin{array}{l}\text { 1) Restoration plan (consistent with } \\
\text { Ramsar Convention Guidelines; verified } \\
\text { every } 5 \text { years) } 2 \text { ) climate benefit analysis } \\
\text { (net balance after } 20 \text { years higher than } \\
\text { baseline, veryfied every } 5 \text { years) } 3 \text { ) } \\
\text { Additionality 4) Guarantee of permanence }\end{array}$ & $x$ & & - \\
\hline \multicolumn{6}{|l|}{ Manufacturing } \\
\hline $\begin{array}{l}\text { Manufacture of low } \\
\text { carbon technologies }\end{array}$ & $\begin{array}{l}\text { List of products \& technologies for } \\
\text { eligible renewable energy } \\
\text { technologies; vehicles with low or zero } \\
\text { tailpipe emissions; energy efficient } \\
\text { equipment for buildings, etc. }\end{array}$ & now subdivided into below categories & $x$ & & \multirow[b]{2}{*}{71} \\
\hline $\begin{array}{l}\text { Manufacture of } \\
\text { renewable energy } \\
\text { technologies }\end{array}$ & $\begin{array}{c}\text { part of low-carbon technologies in the } \\
\text { TEG report }\end{array}$ & $\begin{array}{l}\text { The economic activity manufactures } \\
\text { renewable energy technologies, is an } \\
\text { enabling activity, it is an activity classified } \\
\text { under NACE codes C. } 25 \text { (fabricated metal } \\
\text { products), C. } 27 \text { (electrical equipment), } \\
\text { C. } 28 \text { (machinery and equipment) }\end{array}$ & $\mathrm{x}$ & & \\
\hline
\end{tabular}


Manufacture of equipment for the production of hydrogen

Manufacture of low carbon technologies for transport

\section{Manufacture of} energy efficiency equipment for buildings

Manufacture of other low carbon technologies

Manufacture of Cement part of low-carbon technologies in the TEG report part of low-carbon technologies in the TEG report
The economic activity manufactures

hydrogen electrolysis technologies, It

is an enabling activity, the activity is classified under NACE codes C.25, C.27, C. 28

Manufacture of low carbon transport vehicles, fleets and vessels and key components (for all transport modes specified in transport activities), it is an enabling activity, it is an activity classified under NACE codes C.27, C.29 (motor vehicles, trailers and semi-trailers), C.30 (other transport equipment)

Manufacture of energy efficiency equipment for buildings, It is an enabling activity, classified under NACE codes C.16, C.17, C.22, C.23, C.25, C.27, C.28, see list of eligible components

Manufacture of low carbon technologies that result in substantial GHG emission reductions in other sectors of the economy (demonstrating substantial LCA savings compared to best performaing alternative, verified by independent third party), enabling activity, activities classified under C. $10-$ C.33

Specific emissions $<0.766$ tCO2e/t of EU ETS Benchmark 2021-2026 (tCO2e per clinker or $<0.498$ tCO2e/t of cement or alternative binder (EU-ETS benchmark) tonne of grey cement clinker or per tonne

of cement or alternative binder, using 0.65 clinker to cement ratio) 


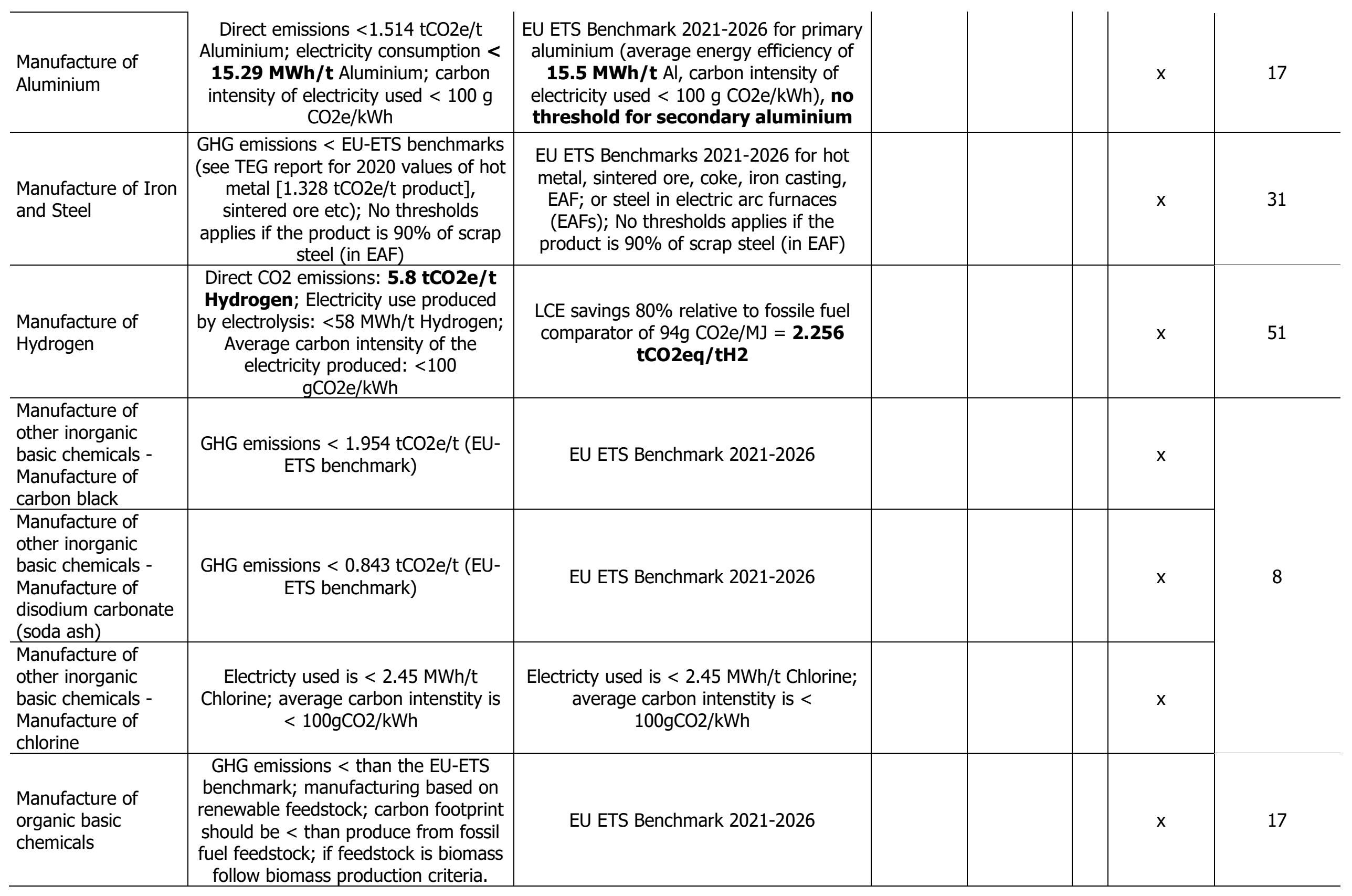


Manufacture of

anhydrous

ammonia, nitric acid

(formerly:

Manufacture of

fertilizers and

nitrogen

compounds)

\section{Manufacture of} plastics in primary

form
GHG emissions < ETS benchmark:

0.302 tCO2e/t for nitric acid; Scope 1

emissions lower than 1

tCO2/tAmmonia; Combined CO2 emissions lower than 1,3 tCO2/t Ammonia

manufactured by mechanical recycling or chemical recycling or from renewable feedstock; renewable

feedstock refers to biomass, industrial bio-waste or municipal bio-waste;

$90 \%$ of the final plastic is not single use or based on recycled plastics as feedstock

EU ETS Benchmark 2021-2026 for ammonia \& nitric acid

\section{Electricity, gas, steam and air conditioning supply}

\section{Production of}

Electricity,

(Cogeneration of) Heat/Cool (and

Power) from Solar

PV, Concentrated

Solar Power, Wind

Power, Ocean

Energy

Production of

Electricity from

Hydropower

Facilities operating at LCE <

$100 \mathrm{gCO} 2 \mathrm{e} / \mathrm{kWh}$, declining to 0gCO2e/kWh by 2050 (threshold will be reduced every 5 years)

\section{Production of}

Electricity,

(Cogeneration of)

Heat/Cool (and

Power) from

Geothermal Energy

fully manufactured by mechanical or chemical recycling of plastic waste; LCE lower than life-cycle GHG emissions of the equivalent primary plastic manufactured from fossil fuel feedstock; Food or feed crops are not used as bio-based feedstock for the manufacture of plastic in primary form.

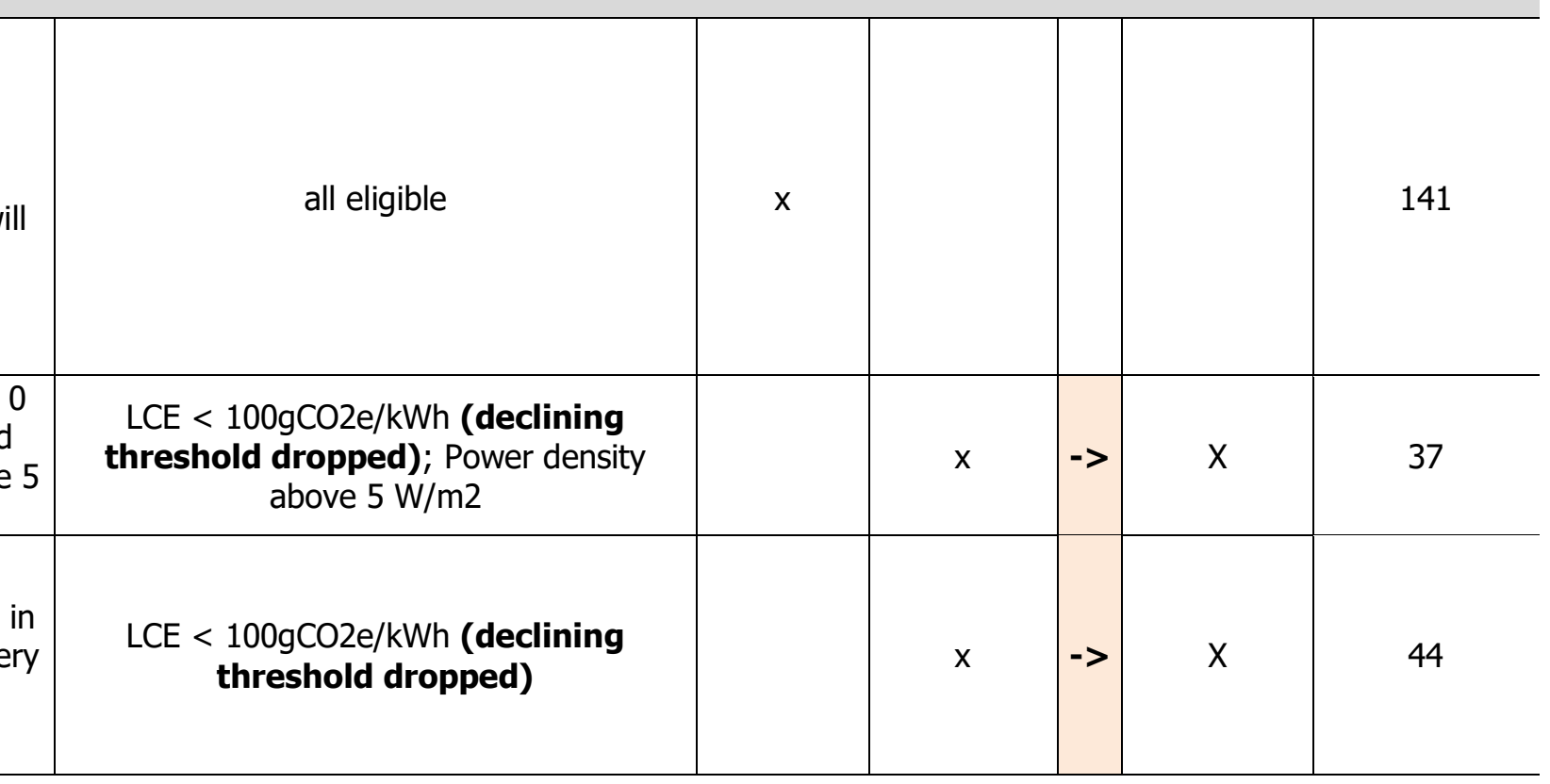




\section{Production of}

Electricity,

(Cogeneration of)

Heat/Cool (and

Power) from Gas

(not exclusive to

natural gas)

Production of

Electricity,

(Cogeneration of)

Heat/Cool (and

Power) from

Bioenergy (Biomass,

Biogas and Biofuels)

Eligible if 'trajectory to full

decarbonisation' (either $\mathbf{6 7 \%}$ of

newly connected capacity is

Transmission and

Distribution of

Electricity

elow $100 \mathrm{gCO} 2 \mathrm{e} / \mathrm{kWh}$ or average

grid emission factor is below $\mathbf{1 0 0}$

$\mathbf{g C O 2} / \mathbf{k W h}$ ), not eligible if direct

connection to power plant with >

$100 \mathrm{gCO} 2 \mathrm{e} / \mathrm{kWh}$. Derogation for

European System and subordinated

systems considered eligible (subject to review)

Storage of

Electricity, Thermal

Energy, Hydrogen
Eligible (subject to regular review);

hydrogen, only if infrastructure uses taxonomy eligible hydrogen
LCE $<100 \mathrm{gCO} 2 \mathrm{e} / \mathrm{kWh}$ (declining

threshold was dropped); methane leakage detection and control

1) Agriculture and forest biomass comply with RED 2) $80 \%$ emission reduction

compared to fossil fuel facility (declining

threshold dropped) // does not apply

installations with total rated thermal input

below $2 \mathrm{MW}$ and using gaseous biomass

fuels.// 50-100MW: high-efficiency

cogeneration or BAT, $>100 \mathrm{MW}$ : attain at

least $36 \%$ electrical efficiency, highly

efficient CHP or use CCS

1) Interconnected European system; 2) either $\mathbf{6 7 \%}$ of newly connected capacity is below $100 \mathrm{gCO} 2 \mathrm{e} / \mathrm{kWh}$ or average grid emission factor is below $100 \mathrm{gCO} / \mathrm{kWh}$

Electricity: closed-loop pumped hydropower storage, Pumped storage connected to river bodies are not eligible; Hydrogen: meets the criteria for manufacture of hydrogen; 
Manufacture of

Biogas or Biofuels

Comply with Renewable Energy

Directive; Methane leakage control digestate used as fertilizer

Retrofit of Gas

Transmission and Distribution

Networks

\section{District}

Heating/Cooling

Distribution

Installation and operation of Electric

Heat Pumps

Production of

Heat/cool using

Waste Heat

Eligible for integration of captured $\mathrm{CO}_{2}$; hydrogen or other low carbon gas Energy Efficiency Directive; modification to lower temperature are always eligible Potential $\leq$ 675; Compliance with Ecodesign Framework Directive waste heat.
Comply with Renewable Energy Directive, Food-and feed crops are not used in the activity for the manufacture of biofuels for use in transport 2) Emission reduction of at least $65 \%$ in relation to fossil fue comparator 3) production of digestate meets taxonomy criteria

Eligible if the systems comply with EU regimes and advanced pilot systems

Refrigerant threshold: Global Warming

The activity produces heat/cool from
1) Only networks dedicated to hydrogen or other low-carbon gases; 2) activity includes leak detection and repair of existing gas pipelines to reduce methane leakage

Eligible if the systems comply with EU Energy Efficiency Directive; modification to lower temperature regimes and advanced pilot systems are always eligible

Refrigerant threshold: Global Warming Potential $\leq 675$; Compliance with Ecodesign Framework Directive

The activity produces heat/cool from waste heat.

\section{Water, sewerage, waste and remediation}

Water collection, treatment and supply

Option 1 - absolute threshold: max.

0.5 kwh per m3 water supply; Option

2 - relative threshold: reduced energy consumption by at least $-20 \%$ OR

reduced water leakage between actual and target leakage $>=-20 \%$ (with target leakage $=$ ILI of 1.5$)$

Renewal of water collection, treatment and supply systems not included in TEG report
Energy consumption lower than $0.5 \mathrm{kWh}$ per cubic meter water supply; b) the leakage level, calculated using the Infrastructure Leakage Index (ILI)381 rating method, equals to or is lower than 1.5 .

Decrease energy consumption by at least $\mathbf{2 0 \%}$ and closing the gap by at least $20 \%$ between the current leakage level, and an ILI of 1.5 
Centralized

wastewater

treatment

New wastewater treatment facility substitutes more GHG emission

intensive wastewater treatment systems

Renewal of waste water collection and treatment

not included in TEG report

Eligible if methane leakage is

Anaerobic Digestion of bio-waste or sewage sludge controlled and if biogas is used for electricity production, upgraded to bio-methane, used as vehicle fuel or as feedstock in the chemical industry; digestate produced is used as fertilize

Separate collection and transport of non-hazardous

waste in source segregated fractions

source segregated waste (in single or co-mingled fractions) is separately collected with the aim of preparing for reuse and/or recycling.

Source segregated and separately collected biowaste ( $>70 \%$ of input) Co-digestion is eligible only with a minor share; methane leakage is controlled by a monitoring plan; compost is used as fertilizer; direct use of biogas produced

Material recovery from non-hazardous waste
$50 \%$ (in terms of weight) of the processed and separately collected non-hazardous waste is converted into secondary raw materials
New: The front-to-end waste water system, including collection, treatment and discharges of waste water, has net zero energy use, demonstrated on an annual basis.

At least 10\% energy use reduction

1) monitoring plan is in place for methane leakage at the facility 2) biogas is used for generation of electricity or heat, upgraded to bio-methane or used as vehicle fuel or as feedstock in chemical industry //

sewage: bio-waste constitutes at least 90

$\%$ of the input feedstock, measured in weight; other input material may not include food or feed crops.

All separately collected and transported non-hazardous waste that is segregated at source, including co-mingling, is sent to preparation for reuse or recycling.

1) bio-waste that is composted is source segregated and collected separately 2) compost produced is used as fertiliser or soil improver and meets the requirements for fertilising materials

at least $50 \%$, in terms of weight, of the processed separately collected nonhazardous waste is converted into secondary raw materials 
Permanently closed landfill from before 2019; Gas is used for electricity

Landfill gas capture and utilization

production, upgraded to bio-methane

used as vehicle fuel or feedstock in

the chemical industry; methane emissions and leakage are controlled

Direct Air Capture of $\quad$ all eligible
$\mathrm{CO} 2$

\begin{tabular}{|c|c|}
\hline $\begin{array}{l}\text { Capture of } \\
\text { anthropogenic }\end{array}$ & $\begin{array}{c}\text { eligible if } \mathrm{CO} 2 \text { is sequestrated in } \\
\text { eligible facilities. }\end{array}$ \\
\hline
\end{tabular}

emissions eligible facilities

Transport of $\mathrm{CO} 2$

eligible if the leakage/t CO2 <0,5\%

\section{Permanent}

Sequestration of

captured $\mathrm{CO} 2$

compliance with ISO 27914:2017
1) landfill has not been opened after 8 July 2020; 2) landfill or landfill cell where the gas capture system is newly installed, extended, or retrofitted is permanently closed and is not taking further biodegradable waste. 3) gas is used for the generation of electricity or heat as biogas 4) methane emissions are controlled

Not included in Draft Delegated Act

1) leakage/t CO2 < 0,5\% of mass of $\mathrm{CO} 2,2) \mathrm{CO} 2$ is delivered to a permanent CO2 storage site 3) Appropriate leak detection systems are applied 4) assets that increase the flexibility and improve the management of an existing network

1) Characterisation and assessment of the potential storage complex and surrounding area (exploration) is carried out 2) appropriate leakage detection systems are implemented 3) activity complies with Directive 2009/31/EC and ISO 27914:2017 for geological storage of $\mathrm{CO} 2$

\section{Buildings}

Construction of new buildings

Net primary energy demand of the new construction must be at least $20 \%$ lower than the primary energy demand resulting from the relevant NZEB requirements
Net primary energy demand: at least 20\% lower than NZEB requirements; NEW: buildings $>5000 \mathrm{~m} 2$, upon completion, building undergoes testing for airtightness and thermal integrity \& life cycle Global Warming Potential (GWP) of the building has been calculated 


\begin{tabular}{|c|c|c|c|c|c|}
\hline Building renovation & $\begin{array}{c}\text { Major renovation' from EPBD or }-30 \% \\
\text { energy consumption (baseline } \\
\text { performance and predicted } \\
\text { improvement shall be based on a } \\
\text { specialised building survey and } \\
\text { validated by an accredited energy } \\
\text { auditor) }\end{array}$ & $\begin{array}{l}\text { Major renovation' from EPBD or }-30 \% \\
\text { energy consumption (initial primary } \\
\text { energy demand and estimated } \\
\text { improvement based on building survey or } \\
\text { energy audit and and validated by an } \\
\text { accredited energy auditor) }\end{array}$ & & $x$ & 51 \\
\hline $\begin{array}{l}\text { Individual } \\
\text { renovation } \\
\text { measures, } \\
\text { installation of } \\
\text { renewables on-site } \\
\text { and professional, } \\
\text { scientific and } \\
\text { technical activities }\end{array}$ & $\begin{array}{l}\text { Must comply with Energy Performance } \\
\text { Building Directive (EPBD), and must } \\
\text { meet Ecodesign requirements }\end{array}$ & $\begin{array}{l}\text { Must comply with Energy Performance } \\
\text { Building Directive (EPBD), and must meet } \\
\text { class A in Ecodesign requirements }\end{array}$ & $x$ & & 41 \\
\hline $\begin{array}{l}\text { Installation, } \\
\text { maintenance and } \\
\text { repair of charging } \\
\text { stations for electric } \\
\text { vehicles in buildings }\end{array}$ & Not included in TEG report & $\begin{array}{l}\text { Installation, maintenance or repair of } \\
\text { charging stations for electric vehicles. }\end{array}$ & $x$ & & - \\
\hline $\begin{array}{l}\text { Installation, } \\
\text { maintenance and } \\
\text { repair of } \\
\text { instruments and } \\
\text { devices for } \\
\text { measuring, } \\
\text { regulation and } \\
\text { controlling energy } \\
\text { performance of } \\
\text { buildings }\end{array}$ & Not included in TEG report & $\begin{array}{l}\text { Smart thermostats, building automation, } \\
\text { energy management systems, smart } \\
\text { meters, facade and roofing elements with } \\
\text { solar shading etc. }\end{array}$ & $x$ & & - \\
\hline $\begin{array}{l}\text { Installation, } \\
\text { maintenance and } \\
\text { repair of renewable } \\
\text { energy technologies }\end{array}$ & Not included in TEG report & $\begin{array}{l}\text { Installation of all types of renewable } \\
\text { energy technologies (see list) }\end{array}$ & $x$ & & - \\
\hline
\end{tabular}


Acquisition and ownership of buildings
Calculated performance of the building must be within the top $15 \%$ of the local existing stock in terms of operational Primary Energy Demand
1) Buildings built before 31 December 2020, the building has at least EPC class A; 2) buildings built after 31 December 2020, the building meets the criteria set out for the activity 'construction of new buildings'; 3) large non-residential

builsings are efficiently operated through energy performance monitoring and assessment

\section{Transportation and storage}

\begin{tabular}{|c|c|c|c|c|c|c|c|}
\hline $\begin{array}{l}\text { Passenger } \\
\text { cars and commercial } \\
\text { vehicles (renamed: } \\
\text { Transport by } \\
\text { motorbikes, } \\
\text { passenger cars and } \\
\text { light commercial } \\
\text { vehicles) }\end{array}$ & $\begin{array}{l}\text { Zero tailpipe emissions vehicles, }< \\
50 \mathrm{gCO} 2 / \mathrm{km} \text { (vehicle } \mathrm{km} \text { ) until } 2025 \\
\text { (from } 2026 \text { only } 0 \mathrm{~g} \mathrm{CO} / \mathrm{km} \text { (WLTP) }\end{array}$ & $\begin{array}{c}\text { Zero tailpipe emissions vehicles, or < } \\
50 \mathrm{gCO} 2 / \mathrm{km} \text { until } 2025(\mathrm{WLTP}) / / \text { vehicles } \\
\text { of category L: the tailpipe } \mathrm{CO} 2 \text { emissions } \\
\text { equal to } 0 \mathrm{~g} \mathrm{CO2e} / \mathrm{km}\end{array}$ & & $x$ & & & 47 \\
\hline $\begin{array}{l}\text { Operation of } \\
\text { personal mobility } \\
\text { devices }\end{array}$ & Not included in TEG report & $\begin{array}{l}\text { 1) propulsion of personal mobility devices } \\
\text { comes from the physical activity of the } \\
\text { user, from a zero-emissions motor, or a } \\
\text { mix of zero-emissions motor and physical } \\
\text { activity 2) The personal mobility devices } \\
\text { are allowed to be operated on the same } \\
\text { public infrastructure as bikes or } \\
\text { pedestrians }\end{array}$ & $x$ & & & & - \\
\hline $\begin{array}{l}\text { Passenger Rail } \\
\text { Transport } \\
\text { (Interurban) }\end{array}$ & $\begin{array}{l}\text { Zero direct emissions trains, } \\
<50 \mathrm{gCO} \text { e/pkm until 2025, to be } \\
\text { reviewed }\end{array}$ & $\begin{array}{l}\text { Trains and passenger coaches have (a) } \\
\text { zero direct (tailpipe) CO2 emissions or (b) } \\
\text { have zero direct tailpipe } \mathrm{CO} 2 \text { emission } \\
\text { when operated on a track with necessary } \\
\text { infrastructure, and use a conventional } \\
\text { engine where such infrastructure is not } \\
\text { available (bimode) }\end{array}$ & & $x$ & $<-$ & $x$ & 23 \\
\hline $\begin{array}{l}\text { Public transport } \\
\text { (renamed: Urban, } \\
\text { suburban and road } \\
\text { passenger } \\
\text { transport) }\end{array}$ & $\begin{array}{c}\text { Zero direct emissions trains, or < } \\
50 \mathrm{gCO} 2 \mathrm{e} / \mathrm{pkm} \text { (passenger } \mathrm{km} \text { ) until } \\
2025 \text {, to be reviewed }\end{array}$ & $\begin{array}{l}\text { The direct (tailpipe) CO2 emissions of the } \\
\text { vehicles are zero }\end{array}$ & & $x$ & $<-$ & $x$ & 39 \\
\hline
\end{tabular}


Freight rail

Transport

Freight transpor
services by road

services by road

Zero direct emissions vehicles, direct emission $<50 \%$ of the reference $\mathrm{CO} 2$ emissions in the subgroup

Zero direct emissions vehicles, $<$

$50 \mathrm{gCO} / \mathrm{pkm}$, to be reviewed in 2025 ;

Vehicles solely using advanced

biofuels or renewable liquid and

Interurban

scheduled road

transport

gaseous transport fuels of non-

biological origin (for investment in

new vehicles of this type: only vehicles emissions below $95 \mathrm{~g} \mathrm{CO} 2 \mathrm{e} / \mathrm{pkm}$ )

\section{Infrastructure for}

low carbon

transport (land

transport)

Infrastructure required for zero direct emissions transport, active mobility, and predominantly used for eligible low carbon transport; transport of fossil fuels is not eligible

Infrastructure required for zero direct

Infrastructure for low carbon transport (water transport)
Trains and wagons have (a) zero direct (tailpipe) $\mathrm{CO} 2$ emissions or (b) have zero direct tailpipe $\mathrm{CO} 2$ emission when operated on a track with necessary infrastructure, and use a conventional engine where such infrastructure is not available (bimode)

'Zero-emission heavy-duty vehicles' as defined in Article 3, point (11), of

Regulation (EU) 2019/1242; above 7.5 tonnes: or 'low-emission heavy-duty

vehicles' as defined in Article 3, point (12) of that Regulation. // Vehicles are not dedicated to transporting fossil fuels

Not included in Draft Delegated Act

Infrastructure is a) dedicated to the operation of vehicles with zero tailpipe $\mathrm{CO} 2$ emissions $b$ ) transhipping freight between the modes $\mathrm{c}$ ) dedicated to public passenger; not dedicated to the transport of fossil fuels

Infrastructure a) dedicated to operations of zero direct (tailpipe) emissions, b) to the provision of shore-side electric power to vessels at berth, c) to the performance of the ports own operations with zero emissions, d) to transhipping freight between modes; infrastructure is not dedicated to the transport of fossil fuels 


\begin{tabular}{|c|c|c|c|c|c|}
\hline $\begin{array}{l}\text { Inland passenger } \\
\text { water transport }\end{array}$ & $\begin{array}{c}\text { Zero direct emissions vehicles; } \\
\text { advanced biofuels or renewable liquid } \\
\text { and gaseous transport fuels of non- } \\
\text { biological origin, }<50 \mathrm{gCO} 2 / \mathrm{pkm} \text {, to } \\
\text { be reviewed in } 2025\end{array}$ & $\begin{array}{l}\text { Vessels have (a) zero direct (tailpipe) CO2 } \\
\text { emissions or (b) until } 31 \text { December } 2025 \text {, } \\
\text { hybrid vessels use at least } 50 \% \text { of zero } \\
\text { direct (tailpipe) CO2 emission fuel mass or } \\
\text { plug-in power for their normal operation }\end{array}$ & & $x$ & 22 \\
\hline $\begin{array}{l}\text { Inland freight water } \\
\text { transport }\end{array}$ & $\begin{array}{c}\text { Zero direct emissions vehicles; direct } \\
\text { emission }<50 \% \text { of the reference CO2 } \\
\text { emissions in the subgroup }\end{array}$ & $\begin{array}{l}\text { 1a) Zero direct emissions vehicles or b) } \\
\text { direct emission }<50 \% \text { of the reference } \\
\text { CO2 emissions in the subgroup; } 2 \text { ) Vessels } \\
\text { purchased or operated are not dedicated } \\
\text { to transport fossil fuels }\end{array}$ & & $x$ & 23 \\
\hline $\begin{array}{l}\text { Infrastructure for } \\
\text { personal mobility }\end{array}$ & $\begin{array}{c}\text { Part of low-carbon transport in the } \\
\text { TEG report }\end{array}$ & $\begin{array}{c}\text { Personal mobility: pavements, bike lanes } \\
\text { and pedestrian zones, electrical charging } \\
\text { and hydrogen refuelling installations for } \\
\text { personal mobility devices }\end{array}$ & $x$ & & - \\
\hline $\begin{array}{l}\text { Infrastructure for } \\
\text { rail transport }\end{array}$ & $\begin{array}{c}\text { Part of low-carbon transport in the } \\
\text { TEG report }\end{array}$ & $\begin{array}{l}\text { Infrastructure a) electrified trackside } \\
\text { infrastructure and associated subsystems } \\
\text { or trackside infrastructure and associated } \\
\text { subsystems where there is a plan for } \\
\text { electrification/use zero tailpipe CO2 } \\
\text { emission trains within } 10 \text { years, b) the } \\
\text { infrastructure and installations are } \\
\text { dedicated to transhipping freight between } \\
\text { the modes, c) infrastructure and } \\
\text { installations are dedicated to the transfer } \\
\text { of passengers from other modes to rail }\end{array}$ & $x$ & & - \\
\hline $\begin{array}{l}\text { Low carbon airport } \\
\text { infrastructure }\end{array}$ & Not included in TEG report & $\begin{array}{l}\text { Infrastructure a) dedicated to the } \\
\text { operation of aircraft with zero tailpipe } \mathrm{CO} 2 \\
\text { emissions, } \\
\text { b) to the provision of fixed electrical } \\
\text { ground power and preconditioned air to } \\
\text { stationary aircrafts, } \\
\text { c) to the zero direct emissions } \\
\text { performance of the airport's own } \\
\text { operations: electric charging points, } \\
\text { electricity grid connection upgrades, } \\
\text { hydrogen refuelling stations; infrastructure } \\
\text { is not dedicated to the transport of fossil } \\
\text { fuels }\end{array}$ & $x$ & & - \\
\hline
\end{tabular}


Retrofitting inland water passenger and freight transport

Sea and coastal freight water transport

Sea and coastal passenger transport

Not included in TEG report

Retrofit of sea and
coastal water

transport

Not included in TEG report
Until 2025, the retrofitting activity reduces fuel consumption of the vessel by at

least $\mathbf{1 0} \%$ expressed in litre of fuel per tonne kilometre, not dedicated to transport fossil fuels

Vessels have zero direct (tailpipe) $\mathrm{CO} 2$ emissions; or (b) until 2025 , hybrid vessels use at least $50 \%$ of zero direct (tailpipe) $\mathrm{CO} 2$ emission fuel mass or plugin power for their normal operation; or c) until 2025 direct (tailpipe) $\mathrm{CO} 2$ emissions $50 \%$ lower than the average reference $\mathrm{CO} 2$ emissions value // Vessels are not dedicated to the transport of fossil fuels Vessels have zero direct (tailpipe) $\mathrm{CO} 2$ emissions; or (b) until 2025, hybrid vessels use at least $50 \%$ of zero direct (tailpipe) $\mathrm{CO} 2$ emission fuel mass or plugin power for their normal operation; or c) until 2025 vessels have an attained Energy Efficiency Design Index (EEDI)469 value

$10 \%$ below the EEDI requirements applicable on 1 January 2022

Until 31 December 2025, the retrofitting activity reduces fuel consumption of the vessel by at least $\mathbf{1 0} \%$ expressed in grams of fuel per deadweight tons per nautical mile, not dedicated to transport of fossil fuels

\section{ICT}

Data processing, hosting and related activities
The data centre implements the European Code of Conduct for Data Centre Energy Efficiency or in CENCENELEC document CLC TR50600-991
1) Data centre implements the European Code of Conduct for Data Centre Energy Efficiency or in CEN-CENELEC document CLC TR50600-99-1; 2) The global warming potential (GWP) weighted average for the mixture of refrigerants used in the data centre cooling system does not exceed 10

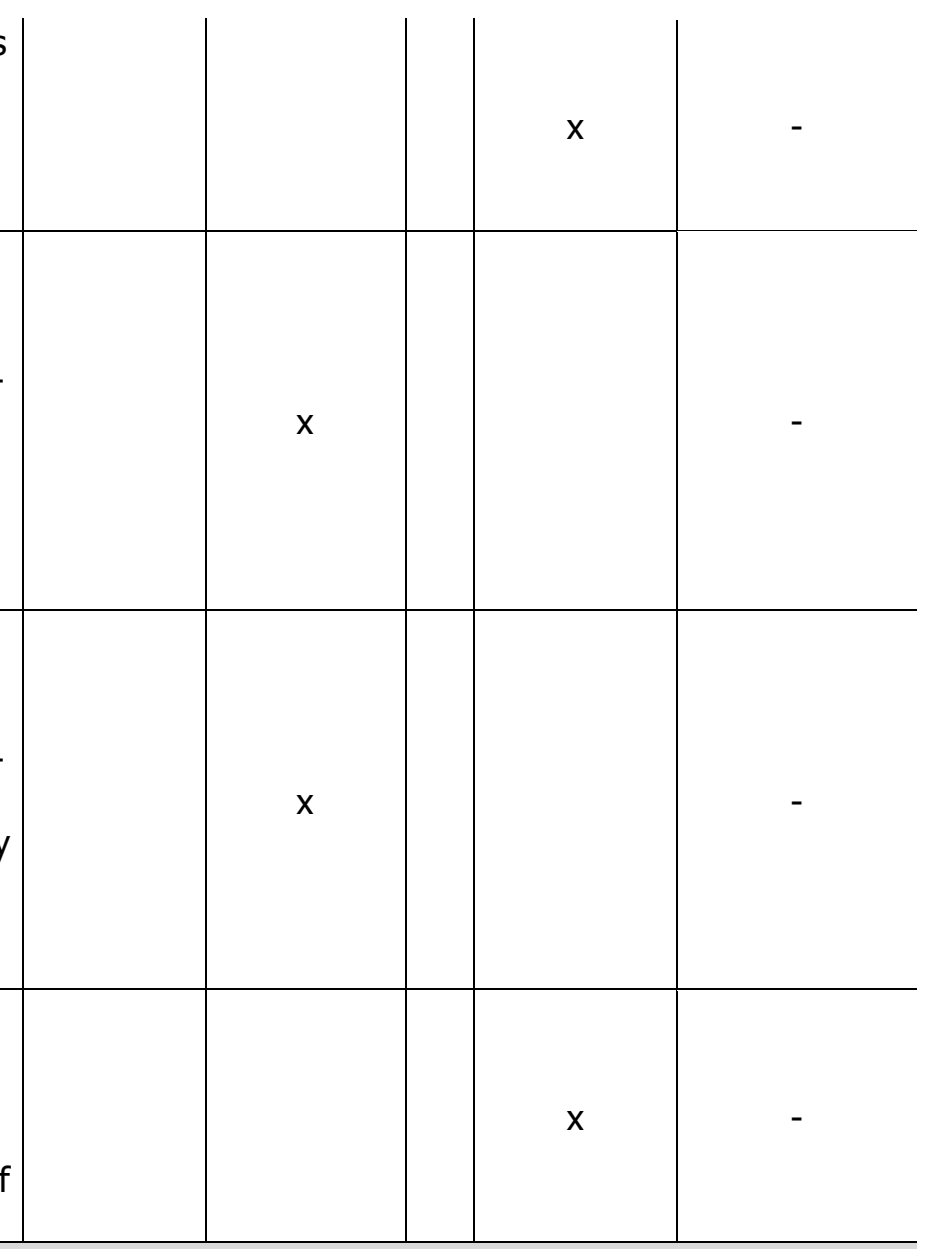

\begin{tabular}{|l|l|l|l|l}
\hline & & & & \\
\hline & & $x$ & 12 \\
\hline
\end{tabular}




\section{Data-driven climate change monitoring} solutions
Solutions are predominantly used for the provision of data and analytics on GHG emissions; demonstrate substantial lifecycle GHG emission savings; verified by independent third party

\section{R\&D}

\begin{tabular}{|c|c|c|c|c|}
\hline $\begin{array}{l}\text { Research, } \\
\text { development and } \\
\text { innovation }\end{array}$ & Not included in TEG report & $\begin{array}{l}\text { 1) The activity researches, develops or } \\
\text { provides innovation for technologies, } \\
\text { products or other solutions that are } \\
\text { dedicated to enable one or more economic } \\
\text { activities for which the technical screening } \\
\text { criteria have been set out in this Annex, } \\
\text { with the exception of activities considered } \\
\text { as transitional and enabling activities in } \\
\text { accordance with Articles } 10(1), \text { point (i), } \\
\text { and } 10(2) \text { of Regulation EU 2020/852 }\end{array}$ & $x$ & - \\
\hline $\begin{array}{l}\text { Professional } \\
\text { services related to } \\
\text { energy performance } \\
\text { of buildings }\end{array}$ & Not included in TEG report & $\begin{array}{c}\text { a) Technical consultation, b) accredited } \\
\text { energy audits and buildings performance } \\
\text { assessments (c) energy management } \\
\text { services; } \\
\text { (d) energy performance contracts; } \\
\text { (e) energy services provided by energy } \\
\text { service companies (ESCOs). }\end{array}$ & $x$ & - \\
\hline
\end{tabular}

Source: Own elaboration of TEG (TEG, 2020b) and European Commission (European Commission, 2020b). 